\title{
Contract Cheating and Academic Integrity in Higher Education: What can Universities, Governments and Quality Assurance Agencies do to Understand, Prevent and Respond to the Challenge?
}

\author{
Dr. Myra E. J. B. Williamson*
}

\begin{abstract}
There is a global challenge to higher education posed by "contract cheating". "Contract cheating" occurs when a student contracts a third party to create an assignment for them, and then the student submits it as their own work. Usually money changes hands, but not always. This particularly insidious form of cheating has been exacerbated by the commodification of higher education and the increasingly popular "sharing economy".

Contract cheating not only threatens the academic integrity of the individual student's grades and their degree, it also raises suspicion about all the degrees awarded by an institution. Globally, universities have been struggling to combat contract cheating. This paper defines and describes the problem and then summarizes the findings of recent research and offers a comprehensive set of solutions.
\end{abstract}

New Zealand was one of the first countries to criminalize contract cheating. Alegal approach is a solution which every country needs to consider because it directly targets the commercial entities creating the product. A pedagogical approach requires universities to be proactive and there are many things which universities can do to manage the problem. A quality assurance approach can involve national quality assurance agencies working with government departments and tertiary education providers to conduct research and provide guidance to all universities. All three approaches are discussed here.

This paper draws on recent research produced by accreditation agencies, individual researchers, and university organizations. It refers to contract cheating research in selected countries-especially New Zealand, Australia and the UK-to counteract contract cheating. The solutions proposed here will be of interest to all universities, quality assurance agencies and governments

\footnotetext{
* BA, LLB Hons, LLM Hons, PhD. Correspondence: drmyrawilliamson@gmail.com. The "last accessed" date for all websites cited herein is 20 March 2019.
} 
because contract cheating is a global problem which challenges the academic integrity of every higher education institution.

Key words: Contract cheating; Student cheating; Outsourcing of assessment; Academic integrity; Essay mills; Teaching and learning practices; Curriculum design. 
"Cheating in any form harms universities, the university system, external parties such as employers who rely on the integrity of qualifications - and students themselves, who can face blackmail and extortion threats from those they pay for 'services.."(1)

\section{Introduction}

Cheating is a global problem which exists in schools, colleges and all types of higher education institutions. Research shows that unethical behaviour and violations of academic integrity occur in the US, ${ }^{(2)}$ Canada, ${ }^{(3)}$ Australia, ${ }^{(4)}$ New Zealand ${ }^{(5)}$ and many other countries. ${ }^{(6)}$ Cheating does not discriminate: it occurs in universities with excellent reputations. In 2013, a study of Harvard freshman showed that $42 \%$ self-reported that they cheated on homework, and $10 \%$ selfreported that they had cheated on exams prior to heading to Harvard. ${ }^{(7)}$ That study followed a 2012 scandal involving 125 Harvard students plagiarizing

(1) Universities New Zealand "We need to talk about cheating" 21 August 2018, available at: https://www.universitiesnz.ac.nz/latest-news-and-publications/we-need-talk-about-cheating.

(2) McCabe, D L and Trevino, L K “Academic Dishonesty: Honour codes and other contextual influences" (1993) 64 Journal of Higher Education 522-538; McCabe D L and Trevino, L K "Individual and contextual influences on academic dishonesty: a multi-campus investigation" (1997) 38 Research in Higher Education 379-396.

(3) Christensen-Hughes, J M and McCabe, D L “Academic misconduct within higher education in Canada" (2006) 36 The Canadian Journal of Higher Education 1-21, available at: http://journals.sfu.ca/cjhe/index.php/cjhe/article/view/183537/183482.

(4) Brimble, $\mathrm{M}$ and Stevenson-Clarke, $\mathrm{P}$ "Perceptions of the prevalence and seriousness of academic dishonesty in Australian universities" (2005) 32 Australian Educational Researcher 19-44.

(5) Universities New Zealand, supra $\mathrm{n} 2$.

(6) Crown, D F and Spiller, M S "Learning from the Literature on Collegiate Cheating: A Review of Empirical Research (1998) 17(6) Journal of Business Ethics 683-700. For a brief summary of some cheating scandals in Russia, South Africa, Nigeria, Mauritius and India, see Mohamedbhai, G "Higher Education: a hotbed of corruption?" Center for International Higher Education, 26 July 2015 available at: https://www.insidehighered.com/blogs/world-view/higher-educationhotbed-corruption.

(7) Moya-Smith, S "Survey: 42\% of Harvard incoming freshmen class cheated on homework" NBC News, 7 September 2013 available at: https://www.nbcnews.com/news/us-news/survey-42-percent-harvardsincoming-freshman-class-cheated-homework-flna8C11095144; as cited in Scrimpshire, A J, Stone, T H, Kisamore, J L and Jawahar, I M "Do Birds of a Feather Cheat Together: How Personality and Relationships Affect Student Cheating” (2017) 15(1) Journal of Academic Ethics 2. Moya-Smith notes that 1,600 Harvard freshmen were emailed the 10 -minute 60 -question survey and $80 \%$ responded. The survey was carried out by The Crimson, the campus newspaper. The results were collected anonymously. Interestingly, more men cheated than women (consistent with other research on cheating); students on sports scholarships cheated more often than those not on sports scholarships (see below for the discussion of the 'Operation Varsity Blues' scandal). 
answers on a take-home test. ${ }^{(8)}$ The problem of cheating is certainly not confined to so-called "lower quality" higher education institutions. ${ }^{(9)}$ Cheating affects all types of higher education institutions and all disciplines. ${ }^{(10)}$

The knock-on effects of cheating continue even after formal education is completed. Unethical practices at school and university are firm predictors for unethical and corrupt workplace practices. ${ }^{(11)}$ Students who cheat at university are more likely to both endorse and commit unethical behaviours once employed. ${ }^{(12)}$ That underlines the urgency to respond to contract cheating in higher education.

This paper discusses "academic integrity", within which is the subset of "student cheating", and within that is one particular type of cheating: "contract cheating". This paper discusses the meaning of contract cheating, why and how students engage in it, and what universities, governments and quality assurance entities can do to address it. Contract cheating is a particularly insidious form of cheating because

(8) Hackett, G K and Robbins, R D “Cheating Scandal Erupts After Short-Answer Questions Added to Congress Exam" The Crimson, 4 September 2012 available at: https:/www.thecrimson.com/ article/2012/9/4/government-exam-harder-questions/.

(9) There is "a prevailing assumption that contract cheating is more likely to occur in higher education providers of 'lower quality'....a senior manager at one of Australia's most prestigious universities described [an exam-cheating scandal] as a 'freakish' singular event, and suggested that elite universities are 'far less exposed to the integrity pressures faced by other education providers'... our research indicates that this is not the case.”: Bretag, T., Harper R., Burton, M., Ellis, C., Newton, P., Rozenburg, P., Saddiqui, S., and van Haeringen, K. "Contract cheating: a survey of Australian university students" (2018) Studies in Higher Education 1-20 at 13 [hereinafter Bretag et al, the student survey].

(10) Elzubier M A and Rizk D E "Exploring perceptions and attitudes of senior medical students and interns on academic integrity" (2003) 37 Medical Education 389-396.

(11) Stone, T H, Jawahar I M., and Kisamore, J L "Predicting workplace misconduct using personality and academic behaviors" in Burke R J, Tomlinson E C and Cooper C L (eds.) Crime and Corruption in Organizations - why it occurs and what to do about it (Surrey, Gower Publishing Ltd: 2009) at 97-99.

(12) See Graves, S M and Austin, S F "Student Cheating Habits: A Predictor of Workplace Deviance" (2008) 3(1) Journal of Diversity Management 15-21 available at: https:/www.researchgate.net/ publication/266243962_Student_Cheating_Habits_A_Predictor_Of_Workplace_Deviance (“the current generation of high school students shows little sense of ethical indignation about cheating and many believe the pressure to do well makes cheating almost a necessity"; see McCabe, D L and Trevino, L K "Individual and Contextual Influences on academic dishonesty: A multicampus investigation" (1997) 38 Research in Higher Education 379-396; McCabe, D, Trevino K and Butterfield, K D Cheating in College: Why Students Do It and What Educators Can Do About It (John Hopkins University Press: 2012). See also Nonnis S and Swift C "An examination of the relationship between of academic dishonesty and workplace dishonesty: A multicampus investigation" (2001) 76(6) The Journal of Education for Business 69-77; and see Stone, Jawahar and Kisamore 2011, ibid at 100 and sources cited therein. 
it is completely intentional and very difficult to detect. ${ }^{(13)}$ By examining contract cheating from three perspectives - pedagogical legislative and quality assurance this paper attempts to contribute something new to the existing literature. It reviews existing research and reports across all three areas, and draws on personal experience, to offer a comprehensive, holistic set of 25 recommendations-a checklist-which is research-informed and can be used by any of the abovementioned entities to tackle contract cheating, but it is especially useful for universities.

The paper is structured as follows. Section 2 introduces the meaning of academic integrity and cheating in a general sense to help establish the overall context. Section 3 discusses contract cheating. Sections 4, 5 and 6 respectively examine what universities, legislatures and quality assurance agencies can do. Section 7 contains an over-arching list of recommendations.

\section{The big picture: academic integrity and student cheating}

\subsection{Academic integrity}

Academic integrity is seemingly always in the news. On 12 March 2019 there were two significant stories. From Germany, it emerged that another German politician was resigning from his post after it became known that he had engaged in plagiarism when writing his $\mathrm{PhD}$ thesis. The "plagiarism hunter", who had previously brought down the German defence minister, the German research minister and now an MP, is Martin Heidingsfelder. He has created a niche market based on checking the legitimacy of $\mathrm{PhD}$ theses for academic misconduct. Those who wish to enter politics go to him first to ensure their $\mathrm{PhD}$ thesis will not bring down their future career plans. ${ }^{(14)} \mathrm{He}$ has also been engaged by Spain to check the PhDs of some politicians there. ${ }^{(15)}$

(13) Lines has demonstrated that it was very easy to purchase assignments in the discipline of history and pass them off as genuine student work. She purchased one undergraduate and one postgraduate paper from 13 essay mills and then submitted them to lecturers for marking. None of the markers failed the work through suspicion of them having been bought - the markers thought they were all genuine student work: see Lines, L "Ghostwriters guaranteeing grades? The quality of online ghostwriting services available to tertiary students in Australia” (2016) 21(8) Teaching in Higher Education 889-914 available at: https://doi.org/10.1080/13562517.2016.1198759.

(14) Matthews, D “Germany's plagiarism hunter spies victory in war on misconduct” Times Higher Education 13 March 2019.

(15) Ibid. Matthews also reports that last year a Spanish newspaper engaged Heidingsfelder to investigate the $\mathrm{PhD}$ of Spain's prime minister, Pedro Sanchez. Proving plagiarism in $\mathrm{PhD}$ theses has taken a political turn, with allegations that it is being used by some to oust political opponents. 
On the same day, the integrity of admissions processes in top US universities was shaken by the biggest admissions scandal in US history. Fifty people including businessmen, celebrities and actors have been indicted by the FBI for paying bribes to get their children admitted into university via "side doors". ${ }^{(16)}$ The scandal, codenamed "Operation Varsity Blues", involves alleged payments by parents to a "consultant" (William Rick Singer), who was operating a fake charity. Singer would in turn pay bribes to SAT and ACT entrance exam administrators, exam proctors, college admissions administrators and sports coaches. ${ }^{(17)}$ Some students had exam impersonators sit their entry exams on their behalf (contract cheating), other students had answers given to them during the entrance exams or had someone correct their answers afterwards. ${ }^{(18)}$ The objective of the bribes was clear: wealthy parents ${ }^{(19)}$ wanted to have their children admitted to universities such as Yale, Stanford, the University of Texas, Georgetown University, the University of Southern California, UCLA and others. ${ }^{(20)}$ This is the largest ever college admissions scandal to be prosecuted by the US Justice Department and the overall value of the bribes is

(16) Barret, D and Zapotosky, M "FBI accuses wealthy parents, including celebrities, in collegeentrance bribery scheme" Washington Post 12 March 2019 available at: https:/www.washingtonpost.com/world/national-security/fbi-accuses-wealthy-parents-including-celebrities-incollege-entrance-bribery-scheme/2019/03/12/d91c9942-44d1-11e9-8aab-95b8d80a1e4f_story. html?utm_term $=.022 \mathrm{e} 8 \mathrm{c} 731024$.

(17) There were two schemes in place: the college entrance exam scheme and the athletic recruitment scheme. As for the former, Singer would arrange someone to sit the entrance exam for students or he would send someone into the exam room to fix whatever the student had got wrong. As for the latter, Singer would pay sports coaches to pretend that they were recruiting a student, even though the student couldn't play that sport (or at least couldn't play it at college level) and they would not otherwise have been eligible for the team: see Rao, S and Yahr, E “Before Lori Laughlin's alleged cheating scandal daughter Olivier Jade made her life at USC a Youtube brand" Washington Post 12 March 2019 available at: https://www.washingtonpost.com/lifestyle/style/before-lori-loughlinsalleged-cheating-scandal-daughter-olivia-jade-made-her-life-at-usc-a-youtube-brand/2019/03/12/ d50b5dda-4502-11e9-8aab-95b8d80a1e4f_story.html?utm_term=.782357ac304d.

(18) The FBI affidavit of FBI Special Agent Laura Smith, indicting the accused, is available here: https:// games-cdn.washingtonpost.com/notes/prod/default/documents/d216435e-e073-41 f6-b6fa-33ed835$\mathrm{d} 053 \mathrm{~d} /$ note/1310d5d4-ef15-4ea9-ad35-5edaac10cbb5.pdf. The specifics of contract cheating during exams is set forth at paragraph 6 a on page 3 of the affidavit. The individuals are charged with conspiracy to commit mail fraud and honest services mail fraud in violation of Title 18, United States Code, Section 2516.

(19) The names of 32 defendants are set forth in Laura Smith's affidavit at p2: ibid.

(20) Basken, P "FBI accuses dozens in elite university admissions bribery case" Times Higher Education 12 March 2019, available at: https://www.timeshighereducation.com/news/fbi-accuses-dozens-eliteuniversity-admissions-bribery-case. 
approximately \$US25 million. ${ }^{(21)}$ This scandal is likely to dominate headlines for some time. Both of these scandals - though obviously different in terms of location and type of cheating - are timely examples of how academic integrity is under threat globally and that no country, nor institution, is immune. They also remind us that all institutions need to be proactive at protecting academic integrity, rather than waiting for a problem to surface.

Academic integrity is "fundamental to teaching, learning, research and the advance of knowledge...it is critical to every aspect of the educational process."(22) The term "academic integrity" is associated with ethics and values. Bretag has observed that "academic integrity" is a multifarious concept which has slightly different meanings in different geographical contexts. ${ }^{(23)}$ In Australia, Bretag asserts that academic integrity is a "multifaceted and multi-stakeholder issue, premised on actions, underpinned by values, and something which goes well beyond the sensationalized scandals of students cheating, plagiarism, and essay mills". ${ }^{24)}$

In the UK, academic integrity has become an "increasing preoccupation" and although it was initially driven by attempts to detect and punish students-for instance, by the widespread acceptance across the sector of Turnitin softwareit has more recently evolved away from student penalization and into "more proactive preventive teaching and learning practices". ${ }^{(25)}$

In the US, academic integrity may be defined as "acting in accordance with values and principles consistent with ethical teaching, learning and scholarship."(26) Higher education in the US has always been based on an intention to instill both knowledge and values in its students. ${ }^{(27)}$ The YaleReport

(21) Roberts, M “The college bribery scandal is all about a myth" Washington Post 13 March 2019 available at: https://www.washingtonpost.com/opinions/2019/03/13/meritocracy-is-myth-this-is-whokeeps-it-alive/?utm_term=.fa7cb2b891be.

(22) Bretag, T "Defining Academic Integrity: International Perspectives - Introduction" in Bretag (ed) Handbook of Academic Integrity (Springer Press, Singapore: 2016) at 62 [hereinafter Bretag Handbook of Academic Integrity].

(23) Bretag consulted 17 authors representing 39 countries and found that it is difficult to reach a consensus on the precise meaning of academic integrity: ibid, at 64 .

(24) Ibid.

(25) Bretag Handbook of Academic Integrity, supra n 23 at 64-65.

(26) Fishman, $T$ "Academic Integrity as an Educational Concept, Concern, and Movement in US Institutions of Higher Learning” in Bretag Handbook of Academic Integrity at 72.

(27) Eight out of the nine earliest universities established in the US were founded mainly to educate aspiring religious ministers: ibid, at 73 citing Brubacher, J S and Rudy, W Higher Education in Transition: A History of American Colleges and Universities: 1636-1956 (New York, Harper and Brothers: 1958). 
$1828^{(28)}$ shows that from the early years, there was an assumption that "one of the main purposes of education was as a means to further students'moral development."(29) Fishman asserts that even in the nineteenth century, when the student population started to become more diversified, and there was a movement away from strict Judeo-Christian ethical principles in universities, "evidence of the initial fusion of religion, morality and education has remained as a testament to their evangelistic origins." ${ }^{(30)}$ The religious and moral foundation of US university education raises an interesting parallel, since universities in the Middle East - such as this one openly acknowledge an intention to educate students with Islamic values. ${ }^{(31)}$ Honesty is just as much a Judeo-Christian value, embedded in the universities of the US in the eighteenth and nineteenth centuries, as it is an Islamic value, underpinning the Gulf universities of the twenty-first century. ${ }^{(32)}$

Recently published research into the understanding of academic integrity by Chinese graduate student studying in the US shows that "academic integrity" is understood and applied quite differently by students from different cultural backgrounds. ${ }^{(33)}$ In addition, students from affluent backgrounds tend to take a more "entitled" approach: research shows that there is a mentality among privileged students "who assume that power and status entitle them to take advantage of their subordinates' work without acknowledgement". ${ }^{(34)}$ Although Chinese students in the US are obviously quite different from Arab students studying in their home country, Jian et al's research makes some interesting and relevant points for Arab countries to consider about the cultural underpinnings of students' appreciation for academic integrity. For instance, researchers observed a "convenience mentality" in Chinese students, meaning

(28) The Yale Report of 1828 was "one of the most influential documents in the history of American higher education" according to The Collegiate Way organization, which has reproduced part of the original report on its website, available at: http://collegiateway.org/reading/yale-report-1828/.

(29) $\mathrm{Ibid}$, at 73 (emphasis added).

(30) Fishman, supra $\mathrm{n} 27$ at 75.

(31) This paper was written with the intention of being presented at, and published by, the Kuwait International Law School, located in Doha City, Kuwait.

(32) For example, see Kuwait International Law School's "Values", the first of which is "Maintaining Arab and Islamic values", available at: https://kilaw.edu.kw/vision-mission-goals-objectives-and-strategicapproaches/\#1543945373674-c5a9f985-267b.

(33) Jian, H, Russell, M and Wang, W "Academic Integrity From China to the United States: The Acculturation Process for Chinese Graduate Students in the United States" (2019) 29(1) Ethics \& Behaviour 51-70 [hereinafter Jian et al]. My thanks to Dr Lynne Parmenter from the University of Waikato for drawing this article to my attention.

(34) Ibid at 53. 
that they believe in specific moral standards, but they still commit academic misconduct for convenience. ${ }^{(35)}$

The meaning of "academic integrity" in modern universities has been explored by the International Centre for Academic Integrity (ICAI). ${ }^{(36)}$ The ICAI currently defines it as "a commitment, even in the face of adversity, to six fundamental values: honesty, trust, fairness, respect, responsibility and courage." (37) The ICAI is a consortium of universities and institutions that is "united to combat cheating and promote integrity in all aspects of education."(38) The ICAI has member institutions from around the world: its members are predominantly from the US and Canada with a few institutional members from the Middle East and elsewhere. ${ }^{(39)}$ Many universities have used the ICAI's broad definition to help frame their own academic integrity policies. For example, the University of Otago in New Zealand draws on the ICAI definition to state that: ${ }^{(40)}$

Academic integrity is the basis for ethical decision-making and behavior in an academic context. It is reflected in norms of acceptable academic practice and is informed by the values of honesty, trust, responsibility, fairness, respect and courage.

(35) Ibid at 54 and the sources cited therein.

(36) The ICAI was initialed based at Duke University when it was founded in 1992 but is now affiliated with the Rutland Institute for Ethics at Clemson University in South Carolina. More information about its activities is available on its website,www.academicintegrity.org. The ICAI is a US-based non-profit organization established in 1992 in response to concerns over student cheating.

(37) International Centre for Academic Integrity (ICAI), "Fundamental Values of Academic Integrity" available at: https://academicintegrity.org/fundamental-values/. The word "currently" refers to the fact that when the ICAI was first established, as the (then) Centre for Academic Integrity, "courage" was not included as one of the values in the first publication of its Fundamental Values of Academic Integrity (1999); it was added in the second publication of its handbook in 2012 to recognize the fact that courage is needed to realize the other values. The ICAI states in its 2012 Fundamental Values of Academic Integrity that courage is necessary in "translating the values from talking points into action - standing up for them in the face of pressure and adversity..." and that simply believing in the fundamental values is not enough.

(38) ICAI, The Fundamental Values of Academic Integrity (ICAI, 2012) available at: https://academicintegrity.org/wp-content/uploads/2017/12/Fundamental-Values-2014.pdf.

(39) The ICAI appears to have only three university member institutions based in the Middle East and North African region: the American University of Beirut, the Cannekale Onsekis Mart University in Turkey and Dar Al Hekma University in Saudi Arabia. If the American University of Afghanistan is included, that would make four. Its total membership appears to be 138 institutions: see ICAI, "Our member Institutions" available at: https://academicintegrity.org/about/our-member-institutions-2/.

(40) University of Otago, “Academic Integrity Policy", took effect on 1 August 2015, available at: https:// www.otago.ac.nz/administration/policies/otago116838.html. 
Not all universities have adopted an Academic Integrity Policy. It is one of the overall recommendations of this paper ${ }^{(41)}$ that all universities should do so. The discussion that precedes the adoption of a policy may raise awareness of academic integrity and it may prevent unethical conduct. An academic integrity policy also openly affirms a university's commitment to academic integrity and it can clarify the institution's expectations of students, staff and administrators.

\subsection{Honesty}

One particular aspect of academic integrity that is especially relevant to this paper is the value of "honesty". This fundamental value relates to practices in teaching, research and administration. The ICAI states that: ${ }^{(42)}$

Honesty is an indispensable foundation of teaching, learning, research and service, and a necessary prerequisite for full realization of trust, fairness, respect and responsibility. It is essential that academic policies and community practices send a clear message that falsification of data, lying, cheating, fraud, theft, and other dishonest behaviours are unacceptable.

Honesty begins with individuals and extends out into the larger community. The value of honesty impacts many different practices. It places obligations not only on students but on faculty members: it requires faculty to be honest in presenting their qualifications, their teaching experience, their membership in organizations and on boards, as well as their credentials. It requires them to act with integrity in their dealings with their students and in supervision (e.g. by recognizing and acknowledging the work of students when they, as supervisors, refer to the students' work in their own publications; ensuring that they are capable and able to supervise students assigned to them). However, "honesty" in an academic setting is usually associated with student cheating.

\subsection{Student cheating}

Student cheating in higher education is a global problem and there is probably isn't an educational institution which has not experienced it. It is not a new problem: a study published in 1941 claimed that there was a "rather large amount of literature on the subject" of cheating in examinations. ${ }^{(43)}$ There

(41) See below at "7. Recommendations".

(42) ICAI, The Fundamental Values of Academic Integrity, supra n 39.

(43) Drake, C A "Why Students Cheat: A Statistical Search for the Incentives Which Induce College Students to Dishonesty on Examinations" (1941) The Journal of Higher Education 12(8) 418420 at 418 . 
is now a significant body of scholarly research on many aspects of student cheating, including why students cheat, when and how often they cheat, and how best to detect and prevent them from cheating. ${ }^{(4)}$

\section{What activities does student cheating entail?}

Student cheating can include any of the following activities: plagiarism, sabotage, deception, fabrication, collusion, impersonation/imposter behavior, bribing, or misrepresentation. ${ }^{(45)}$ Student cheating can be broken down into very specific activities, depending on the intentions of the research. In US research, an online survey asked students if they had participated in any of the following activities: copying a few sentences without footnoting, "padding" a few items in a bibliography, plagiarizing from public material on term papers, getting questions or answers from someone who has already taken the exam, copying from another student on a test or exam, turning in papers that were done entirely or in part by another student and giving answers to another student during an exam. ${ }^{(46)}$

There are many grey areas when it comes to defining cheating. Purchasing notes and sharing course materials with other student may not, per se, amount to cheating but research shows that this type of out-sourcing behavior is a "slippery slope" towards the outright purchasing of assignments. ${ }^{(47)}$

\section{How often does cheating happen?}

As for cheating's prevalence, Donald McCabe, who has been researching in this field since the 1990s, compiled figures based on self-reporting of student cheating via web surveys done between 2002 and 2015. McCabe found that out of approximately 71,300 US college undergraduates (excluding first-years) - a total of $39 \%$ of students - admitted to cheating on written tests, and $62 \%$

(44) For a list of publications on academic integrity, much of which touches on student cheating, see Gallant, T "Twenty Years of Academic Integrity: Top Articles and Book Chapters 2002-2012" (ICAI, 2012) available at: https://academicintegrity.org/wp-content/uploads/2017/12/462c19_88fa30a3dcff4 20bb6b3ea84697d8b1b.pdf.

(45) These examples of breaches of academic integrity are given by Cinali, G "Middle Eastern Perspectives on Academic Integrity: A View from the Gulf Region" in Bretag et al A Handbook of Academic Integrity, supra $\mathrm{n} 22$.

(46) These questions are put to students in an online survey conducted by Donald McCabe and colleagues; the results are reported in McCabe, Butterfield and Trevino Cheating in College, supra $\mathrm{n} 13$ at 58.

(47) Bretag, the student survey, supra n10 at 2 where it is noted that there "is a genuine risk that buying, selling or trading notes are the beginning of a 'slippery slope' towards the outsourcing of graded assessment." 
admitted cheating on written assignments. ${ }^{(48)}$ The corresponding statistics for graduate students were lower, at $17 \%$ for written tests and $40 \%$ for written assignments. These figures - based on US students and excluding first-year students- are certainly cause for concern.

The author could not find definitive statistics for cheating in Middle Eastern universities as a whole, although some small-scale studies have been carried out. ${ }^{(49)}$ Lebanon was the focus of a study carried out by McCabe and two colleagues from the American University of Beirut. ${ }^{(50)}$ They conducted an online survey involving students from one of the three major universities in Lebanon. The students had already signed up to an online community called "Bicharaf" ("honour" in Arabic) and some of those students $(1,317)$ agreed to participate anonymously. The data was collected in respect of the 2003/2004 academic year and was then compared with the data from 12,793 students at seven large US universities. ${ }^{(51)} \mathrm{McCabe}$ and his colleagues made three interesting findings. First, they found substantially higher levels of selfreporting of cheating in Lebanon when compared with the US. In Lebanon, $66 \%$ of students reported they had cheated on a test or exam, compared with $21 \%$ in the US over the same period. Secondly, a student's decision whether to cheat was heavily influenced by the perception of that behavior by one's peers. ${ }^{(52)}$ This led the researchers to conclude that in Lebanon - as in the USit was important to create honour codes amongst students so that peer pressure would make cheating an unacceptable activity. Thirdly, they found that: ${ }^{(53)}$

the collectivist nature of Lebanese society is an important factor underlying its greater self-reported levels of student dishonesty, results which we believe "provide significant support for the view that Lebanese university students are strongly influenced by the norms of the society in which they are raised.'

(48) These statistics are available on the ICAI website at ICAI "Statistics" available at: https://academicintegrity.org/statistics/, but they are based on a body of research described in McCabe, Trevino, and Butterfield Cheating in College, supra n13.

(49) For instance, McCabe, Feghali and Abdullah conducted a survey of 1,543 English-speaking students at schools in Lebanon, in 2002, reduced to 1,317 after removing first-year and graduate students: ibid.

(50) See McCabe, Feghali and Abdullah (2008), ibid.

(51) McCabe, Trevino and Butterfield, supra n 13 at 62.

(52) Emphasis added. This point will be returned to in section 4 where it is suggested that institutions must get their student leaders on board to help create peer pressure against contract cheating.

(53) McCabe, Trevino and Butterfield, supra n 13 at 63. 
What that means is that, within a specific country "campus culture may be the most important influence on academic integrity."(54) The impact of local culture -within the university- can counteract the negative impact of the country's culture and that may especially be true in relation to "idealistic college students who may be eager to improve the culture of their country". ${ }^{(55)}$ This point is also picked up again in the "Recommendations" section below. It is vitally important for a university to create a culture, across campus, that all forms of cheating are unacceptable and it is important to get student leaders on board in communicating that message and embedding it within student campus culture.

The research on cheating in the US is worth returning to because the studies have been on such a large scale and data has been gathered over a long period. ${ }^{(56)}$ First, McCabe found that self-reporting of cheating by students - including students observing other students cheating on tests - has dropped over the years, but in contrast, reports of cheating as observed by faculty members has increased. ${ }^{(57)}$ Secondly, students are becoming more reluctant to admit in anonymous online surveys that they participated in cheating activities. ${ }^{(58)}$ Thirdly, students no longer consider some acts of cheating as cheating. For instance, McCabe found that students increasingly do not consider that "copyand-paste" plagiarism from the internet counts as cheating: only one in four students (24.4\%) in the 2002-2010 survey agreed that cut-and-paste plagiarism from the internet amounts to serious cheating. Thus, when asked to self-report on cheating, some students do not consider that they have cheated at all, because they rationalize or neutralize their behaviours (e.g. they didn't have enough time to do the assignment properly, or the assignment had little learning value, or using the internet is effective time management), and students thus find their own actions to be legitimate. Therefore, students increasingly do not answer

(54) Ibid.

(55) Ibid.

(56) McCabe and colleagues have been conducting the online surveys since 2002 but he has data from a previous dataset compiled by Bower, which dates to 1962 and he uses all of that data in his research findings. For more information, see McCabe, Trevino and Butterfield, supra $\mathrm{n} 13$.

(57) Ibid at 60: "Overall, there has been a decline of 8 percentage points in the number of students who report observing test cheating by other students-from 52\% in 2002/2003 to 44\% in our 2009/2010 survey. Yet in this same period, the number of faculty who say they have observed test cheating rose from 50 to $60 \%$."

(58) Ibid at 60: "Intuitively, it seems to make sense that if students cheat more often, they will be more reluctant to complete a survey, indicating that they do so." 
"yes" when they in fact did participate in cheating behaviours. ${ }^{(59)}$ The limits of using anonymous online surveys of students to detect cheating behavior is recognized in the literature. ${ }^{(60)}$ Nevertheless, the role in educating students about what amounts to serious cheating emerges from McCabe's research.

\section{Why do students cheat?}

To understand the overall problem, it is important for academics to consider why students cheat. There is a lot of research on this question. ${ }^{(61)}$ Mark Brimble of Griffiths University in Australia shows that students cheat for four main reasons. ${ }^{(62)}$ First, for assignment-related reasons (e.g. the assessment is seen to be too difficult, too time-consuming or the deadline conflicts with other deadlines). Second, to help a friend or fellow student. Third, due to a misunderstanding of what is and what is not a breach (e.g. a misunderstanding of what amounts to collusion or cut-and-paste plagiarism, as discussed earlier). Fourth, due to a perception that they will not be caught. Factors that are consistently associated in the literature as leading to a likelihood of cheating include: negative attitudes, lack of confidence, poor study skills, poor writing skills (especially for international students in a Western university setting), a low GPA, undertaking prior breaches, peer behavior and norms, and assessment nature and design. ${ }^{(63)}$ Although all of those reasons and factors also apply to contract cheating, it is argued here that contract cheating has some additional causes or factors, mainly, the commodification of higher education and the movement away from state universities existing in a not-for-profit environment, which was the case

(59) Ibid at 59: "Many students today simply do not consider cut-and-paste plagiarism from the Internet or written sources to be cheating, so when asked on a survey on 'cheating' whether they have engaged in this behavior, many simply say no- even if they have."

(60) Ibid at 60: "Unfortunately, in spite of all the precautions we take to satisfy the requirements of our Institutional Review Board, there is really no way we can convince a student receiving an email invitation to complete a survey that his or her response will remain completely confidential...Others who are skeptical do respond but may intentionally supply false information about their own behavior, just in case."

(61) For instance, see McCabe, Trevino and Butterfield, supra n 13 esp. ch. 4 "Individual Student Characteristics that Influence Cheating" where he cites research on factors such as gender, age, GPA average, type A personality and competitive achievement-striving, self-esteem etc; see Newton P "Academic integrity: A quantitative study of confidence and understanding in students at the start of their higher education" (2015) Assessment and Evaluation in Higher Education 41(3) 482-497; and see Bretag, the student survey, supra n10.

(62) Brimble, M "Why Students Cheat: An Exploration of the Motivators of Student Academic Dishonesty in Higher Education" in Bretag, R (ed.) Handbook of Academic Integrity (Springer Press, Singapore: 2016) chapter 26.

(63) Brimble, ibid, at 664-65. 
several decades ago, towards higher education now being seen as a for-profit commodity. Bretag and Harper have noted that contract cheating: ${ }^{(64)}$
...needs to be situated within the broader context of higher education disruption, one in which the social, political and economic role of universities is undergoing unprecedented change. The massification and internationalization of higher education have led to larger and increasingly diverse student cohorts, often without corresponding growth in institutional funding. As a result, universities have progressively come to operate as commercial enterprises...

The causes of contract cheating include all the normal causes of all types of student cheating, but they also should include an understanding that getting a degree is these days often a commercial decision by students, rather than a decision to undergo a transformative learning exercise. Likewise, universities see themselves as having to gain and maintain "customers" to whom they will provide educational "products" ${ }^{65)}$ Third parties step into that environment by providing some of the material needed for gaining that degree/product. The sharing economy ${ }^{(66)}$ is a new development which, combined with the trends of commercialization and internationalization of higher education, has created a sort of perfect storm in terms of the struggle to maintain academic integrity.

\section{Contract cheating - a particularly insidious type of cheating}

The term "contract cheating" was first coined in the computer coding context by Clarke and Lancaster, who defined it as "the submission of work by students for academic credit which the students have paid contractors to write for them." "(67) More recently, there has been some debate in the literature over whether "contract cheating" includes work produced by family members, employees and friends of the student. Draper and Newton do not require

(64) Bretag et al, the student survey, supra n10.

(65) The authors of the Contract Cheating and Assessment Design Project describe the scenario like this:

“... in order to ensure fiscal self-sufficiency and sustainability university managers focus more on the profit-driven 'business' of education than on the education process itself...universities compete for students who pay for educational 'products' rather than for the opportunity to engage in a transformative educational process.”: see Contract Cheating and Assessment Design Project, "Institution” available at: https://cheatingandassessment.edu.au/institution/.

(66) Also referred to as the "gig economy", the "crowd sourcing economy" and the "collaborative economy", see Bretag et al, the student survey, supra n10 at p14 note 1.

(67) Clarke, R and Lancaster, T "Eliminating the Successor to Plagiarism? Identifying the Usage of Contract Cheating Sites" (2006) Proceedings of the $2^{\text {nd }}$ International Plagiarism Conference available at: https://www.plagiarism.org/assets/Clarke2_fullpaper2006.pdf. 
money to change hands, in their 2017 definition of contract cheating: ${ }^{(68)}$

Contract cheating, as we define it here, is a basic relationship between three actors; a student, their university, and a third party, who completes assessments for the former to be submitted to the latter, but whose input is not permitted...

Clarke and Lancaster were the early researchers in this area who noticed a problem early on, not in relation to essays or fraudulent $\mathrm{PhDs}$, but in relation to student code. They monitored a website called "RentaCoder" to which users would submit a problem and the site would post it, after which another user would provide a solution. Some genuine users submitted bids to the websiteindividuals who needed a solution to their unique coding problem - but after an exhaustive analysis, the researchers found that at least $12.3 \%$ of bids could be classified as contract cheating. Clarke and Lancaster called this "contract cheating" (probably the first use of that term) and claimed not only that this was the successor to "pure plagiarism", but that is was a growing problem, it could not be detected by existing plagiarism detection software (e.g. "Turnitin" software) and that it posed a threat to the integrity of the academic awards made by their academic institutions. ${ }^{(69)}$

The researchers warned that more automated processes of detection would need to be developed and they also advised that "assessments and academic policies need to be redesigned to remove the potential for contract cheating to be committed."(70) This is a point that will be revisited below in section 4 . It is interesting to note that if one Googles "RentaCoder" today, the first hit that appears states that "RentaCoder is now Freelancer" and the new website, Freelancer.com, has branched out away from computer-coding to offering freelance solutions in a host of different areas including copywriting and essay writing.

This website allows anyone to browse the projects that have been posted and allows anyone to make a bid to do the work in that project for a fee that they set. It works in a more direct and open manner than most ghost-writing

(68) See Draper, M J and Newton, P N “A legal approach to tackling contract cheating?” (2017) 13 International Journal for Educational Integrity 11 available at: https://ink.springer.com/article/10.1007/ s40979-017-0022-5 (Draper and Newton include assignments completed by family members and friends within their definition of contract cheating).

(69) Ibid.

(70) Clarke and Lancaster, supra n 68. 
websites, because on most of the latter sites, there is no way to see who has posted a job: the transactions are made privately between the customer and the website administrator, and the website finds a person to write the work for the customer. The websites providing contract cheating are an even bigger problem than the Rentacoder model. However, Rentacoder - now Freelancer - still has what appears to be requests for student work openly posted on it. If one visits the Freelancer.com page and browses for an "essay" anyone can see that many of the essay projects requested are for academic purposes. ${ }^{(71)}$ Figure 1 is a screenshot taken on 18 March 2019 which shows a few examples of current projects posted on Freelancer.com.

Figure 1.

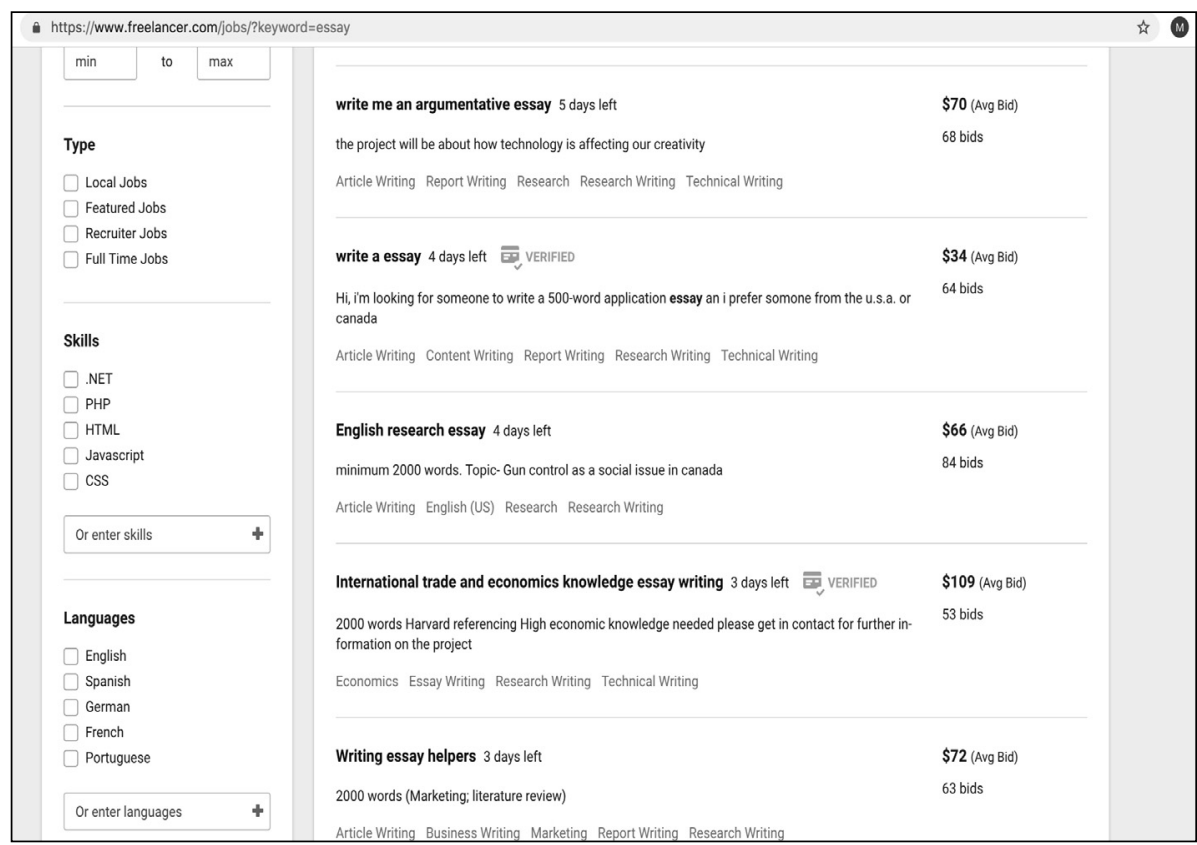

This website, Freelancer.com, allows anyone to anonymously request anyone

(71) The author browsed www.freelancer.com on 5 March 2019 and searched for jobs using the search term "essay". There were bids with the following headings: "Do a ppt for an 8 page paper"; " 1500 word article...IB Extended Essay"; "Philosophy Descarte Essay"; "200 word essay - I need this done within few hours, if you can't do that then please don't bid" [sic]; "Essay Writing - I have an essay to write on the topic (the effect of $\mathrm{CO} 2$ emissions on unemployment rates)". There were many more examples, which anyone can readily see are for school or university credits as no one writes essays for these for any other purpose. 
else to create an article, a PowerPoint, a report or a piece of research - for a mutually agreed fee. Freelancer.com has a model that permits both contract cheating jobs and genuine jobs (e.g. people wanting a website created for them) so they cannot be wholly condemned.

Ghost-writing websites, on the other hand, are far more prevalent and they work differently. They typically invite customers to contact them, and then the website will find a writer for their project. Examples of such websites include Edubirdie.com, Writemyessayforme.org, Domywriting.com, Writemyessayonline.com and so on. There are specific sites targeting masters and doctoral theses such as Thesisrush.com and Thesishelpers.com. There are so many sites that one would be spoilt for choice.

Figure 2 shows a typical landing page for contract cheating websites, complete with guarantees of custom-writing services which are plagiarism-free and which maintain confidentiality.

Figure 2.

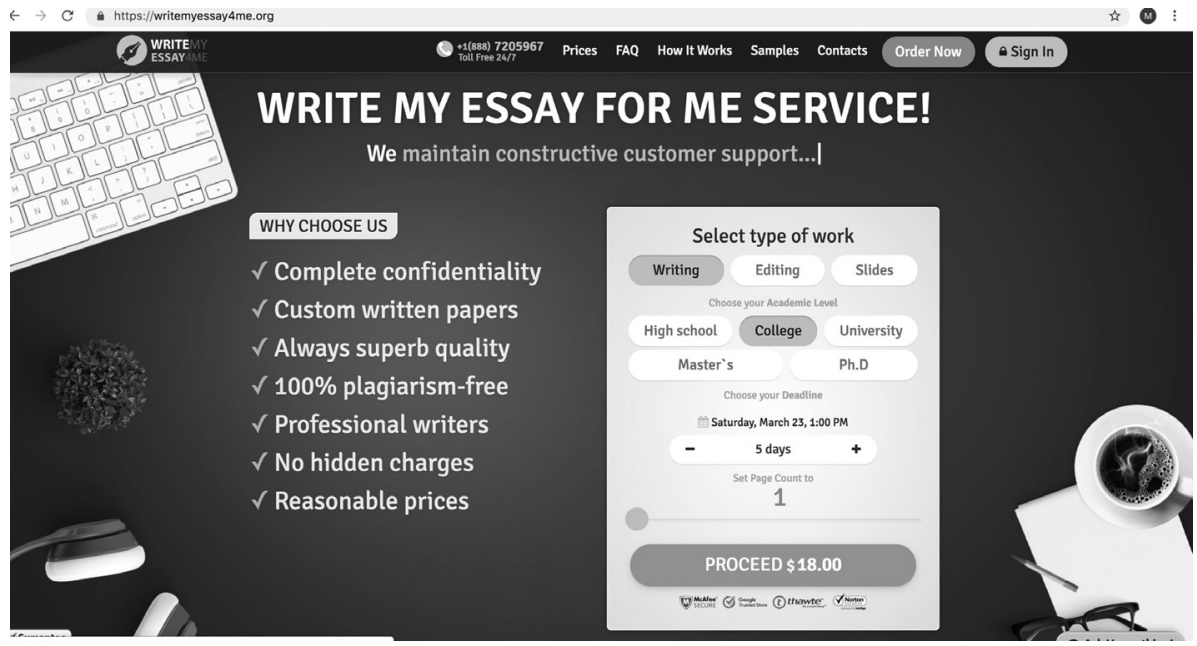

Since Clark and Lancaster coined the term "contract cheating" twenty years ago the problem of contract cheating has not been resolved: in fact, it seems to have grown exponentially worse. The UK's main accreditation agency for higher education, the Quality Assurance Agency (QAA), published a report in 2016 on third parties helping students to cheat. That report was written in response to "serious concerns among HE [Higher Education] providers and 
from sector bodies and the government". (72)

The 2016 report made a number of findings, including that "there is no single solution. Instead we need a multi-faceted approach that builds on published research and the steps that colleges and universities are already taking....". The QAA's 2016 Report led to the publication in 2017 of "Contracting to Cheat in Higher Education: How to Address Contract Cheating, the Use of Third Party Services and Essay Mills" (the QAA 2017 Report), which suggests that a wide range of approaches needs to be adopted urgently to address this issue. ${ }^{(73)}$

The QAA 2016 and 2017 Reports are a must-read for all higher education institutions, whether they be in the UK or beyond. Any quality assurance office in any university would be well-advised to read them. The recommendations put forward by the QAA are based on experience in the UK higher education sector as well as global research into contract cheating. For institutions based in the Middle East, there is a current opportunity to implement the lessons that have already been learnt elsewhere and reap the gains without having to wait for the results of painstaking research or suffer the ignominy of a cheating scandal. ${ }^{(74)}$

\section{What can universities do to prevent and combat contract cheating?}

Higher education institutions have the primary responsibility to combat contract cheating because they are the entities that recruit the students. Bretag and Harper lead a two-year contract cheating research project called Contract Cheating and Assessment Design: Exploring the Connection. It was funded by

(72) QAA, "Plagiarism in Higher Education - Custom essay writing services: an exploration and next steps for the UK higher education sector" (QAA, 2016) available at: https://www.qaa.ac.uk/docs/qaa/ quality-code/plagiarism-in-higher-education-2016.pdf?sfvrsn=308cfe81_4.

(73) QAA, "Contracting to Cheat in Higher Education: How to Address Contract Cheating, the Use of Third Party Services and Essay Mills" (QAA, 2017) available at: https://www.qaa.ac.uk/docs/qaa/ quality-code/contracting-to-cheat-in-higher-education.pdf?sfvrsn=f66af681_8.

(74) Note that the Australian research in the Contract Cheating and Assessment Design project was largely motivated by high profile scandals. For example, SBS broadcast an undercover journalistic expose called Pens for Hire which exposed the problem of students engaging in contract cheating through Chinese-language websites. Students were found to have been engaging third parties to impersonate them in exams, in whole courses and to write essays on their behalf. Another scandal was the "MyMaster" website scandal which led to the expulsion, suspension or other penalization of 70 university students across Australia: see Visentin, L "MyMaster essay cheating scandal: more than 70 university students face suspension" Sydney Morning Herald, 18 March 2015, available at: https://www.smh. com.au/national/nsw/mymaster-essay-cheating-scandal-more-than-70-university-students-face-suspension-20150312-1425oe.html. 
the Australian Government Office for Learning. ${ }^{(75)}$ The project mainly consisted of two large-scale surveys of staff and students which anonymously collected information on attitudes towards, and practices regarding, contract cheating across 12 higher education institutions (eight of which were universities). The research resulted in, inter alia, two published articles setting out the findings. ${ }^{(76)}$ Some of the key advice for universities emerging from that research project, and others, is discussed below. ${ }^{(77)}$ This author will mention eight main areas where institutions need to act.

First and foremost, universities need to acknowledge that contract cheating is happening in their institution: they need to discuss it openly and they need to explain to their students on a regular basis what contract cheating is, why it is wrong, and what penalties they will incur if they engage in it. The Australian research showed that both staff and students did not think contract cheating was being explicitly explained to students. ${ }^{(78)}$ Although the general academic integrity policies might be explained quite well, contract cheating in particular was "not being discussed openly and consistently" by staff. ${ }^{(79)}$ One of the reasons suggested is that since "contract cheating is so evidently "wrong' [staff assume that] it is unnecessary to provide any explanation or education about the issue." ${ }^{(80)}$ Harper states that: ${ }^{(81)}$

Students' lack of concern about contract cheating suggests that conversations between teaching staff and students are needed if the implications of contract cheating are to be understood and the issue meaningfully addressed.

(75) The Contract Cheating and Assessment Design homepage is available at: https://cheatingandassessment.edu.au/. All aspects of the project are described there and the survey questions used by the researchers are also available, which would be useful to anyone looking at replicating their findings.

(76) The student survey results are reported in Bretag, T., Harper R., Burton, M., Ellis, C., Newton, P., Rozenburg, P., Saddiqui, S., and van Haeringen, K. "Contract cheating: a survey of Australian university students" (2018) Studies in Higher Education 1 [referred to herein as Bretag et al, the student survey"]. The staff survey results are reported in Harper, R., Bretag, T., Ellis, C., Newton, P., Rozenburg, P., Saddiqui, S., \& van Haeringen, K. "Contract cheating: a survey of Australian university staff" (2018) Studies in Higher Education 1 [hereinafter "Harper et al, the staff survey"]. In addition to these two excellent journal articles, there were a number of other outputs including workshops and a symposium. Many of these outputs are publicly available on the project's website, Contract Cheating and Assessment Design https://cheatingandassessment.edu.au/.

(77) This discussion offers a necessarily truncated version of the findings and is of course no substitute for reading the original published journal articles.

(78) Harper et al, the staff survey, supra n77 at 13.

(79) Ibid.

(80) Ibid.

(81) Ibid. 
Second, universities need to understand why students engage in contract cheating and then they need to make changes to their teaching and learning environment. Research shows that contract cheating is primarily influenced by high levels of dissatisfaction with the teaching and learning environment, as well as perceptions that there are lots of opportunities to cheat and by students who have Language Other Than English (LOTE) status. ${ }^{(82)}$ Those three reasons align quite closely with earlier research on why students engage in plagiarism (a different form of cheating). ${ }^{(83)}$ Serious forms of cheating are influenced strongly by student dissatisfaction with the teaching and learning environment. This "places responsibility squarely with universities and should prompt serious considerations of approaches to curriculum and assessment design". ${ }^{(84)}$ Simplistic remedies - like a return to high-stakes invigilated exams - are also thought to be counter-productive. ${ }^{(85)}$ Designing assessment which is meaningful, reasonable, timely and closely linked to learning outcomes is the institution's responsibility. Having tighter deadlines is not likely to be useful since providers simply charge more to meet tight deadlines. Assessment can be designed to both reduce the chances of cheating and increase the chances for students to demonstrate their understanding: an oral examination/defence of written assignments would help as would making it obligatory to pass the final exam if there is a large internal assessment component. ${ }^{(86)}$ The QAA's 2017 Report made this recommendation: ${ }^{(87)}$

(82) Bretag et al, the student survey, supra n10 at 14.

(83) Devlin, M and Gray, K "In their own words: a qualitative study of the reasons Australian university students plagiarize" (2007) High Education Research and Development 26(2) at pp181-198. My thanks to Lingling Pan from the University of Waikato for directing me to this interesting paper on plagiarism. Devlin and Gray found that there are 8 main reasons why students plagiarize: 1) Inadequate admission criteria; 2) Poor understanding of plagiarism; 3) Poor academic skills; 4) Teaching/ learning issues; 5) Laziness/convenience; 6) Pride in plagiarism; 7) Pressures; and 8) Education costs. The researchers did not provide data on which reasons were more prominent than others, they were focused on providing the range of reasons that students at one university thought plagiarism occurred.

(84) Bretag et al, the student survey, supra n10 at 14.

(85) Ibid at 14.

(86) The University of Sydney responded to the 2015 cheating scandal in a number of ways. One change they made was to require that students in the Critical Thinking in Business course (which had been plagued by contract cheating) had to pass the final exam in order to pass the course. This was not a "fail-safe" solution, but it was felt that this would help to ensure that contract cheating on assignments would not necessarily result in an overall pass for the course.

(87) QAA 2017 Report, supra n74 at 12. 
A basic principle is to ensure that programmes of study include assessments that allow students to demonstrate their learning practically, in a face-to-face format where possible. Examples include oral presentations (including presentations of written work); practical authentic assessments; placements; contextually specific, personalized assessments; peer assessments; and narrated video presentations.

Personal experience indicates that students in Kuwait will cheat when they feel that they are under extreme time pressure because they cannot cope with the assessment load, an experience that is supported by the literature on cheating. ${ }^{(88)}$ So both assessment and curriculum need to be reexamined: if a typical Kuwaiti student has 5 courses per semester, and each course has a quiz, an assignment, a mid-term and a final, then in one semester there will be a minimum of 20 pieces of graded assessment. Many courses offer a makeup mid-term (or two mid-terms) and more than one quiz so $25-30$ assessment items across a semester is likely to be standard assessment practice. Many of those assessments will conflict in time.

Both the amount and the timing of assessment has to be reconsidered. There should be a discussion about how to ensure quality over quantity of assessment. If a student cannot cope with 25-30 assessment items over 16 weeks - and one wonders which student could cope well with that - then they are more likely to succumb to temptation, visit a student services centre, hand over \$KD20 and get their assignment prepared for them. The timing, number and type of assessments needs to be discussed openly and critically.

English language support and ability is another factor in the teaching and learning environment that has been flagged in the Australian research as a consistent risk factor for contract cheating. In New Zealand, Australia, Kuwait and elsewhere, if a student cannot cope with the language, they are going to feel forced into a situation where they have to purchase an assignment in order to keep up with their course requirements. This is an institutional problem: all institutions must ascertain whether the students they accept into their courses are ready and able to fully participate in those courses. Having adequate language skills upon entry is a key factor for the university to consider.

(88) See Devlin and Gray, supra n84 at 189 wherein students note that "workload amount and timing" is one of the key reasons for engaging in plagiarism. 
The final point regarding the teaching and learning environment is that faculty often believe that they are doing something quite well when students do not agree. ${ }^{(89)}$ Australian students and staff were asked several identical questions, but their answers significantly diverged:

- Is assignment grading consistent?

- Do staff teach scholarship?

- Do staff consistently monitor and penalize academic integrity breaches; and

- Do staff teach referencing?

On each of these questions, staff answered "yes" at much higher levels than the students, and within the student group, those who had admitted to cheating were less likely to answer "yes" than those who had never cheated. ${ }^{\left({ }^{00}\right)}$ This means that every institution should look specifically at these areas to see whether there is room for improvement. Your faculty may think they are doing well in the above four areas, but the reality - as reflected by student responses - may tell a different story.

Thirdly, institutional administrators need to reconsider and closely examine how their faculty relate to their students and how well they know their students. There are two main reasons for forging better relationships between staff and students. First, research shows that students are more likely to cheat when they perceive their educator does not care about them. MacGregor and Stuebs have shown that "students' ethical decision-making may be influenced by the extent to which they have a personal relationship with their educator." ${ }^{(91)}$ Secondly, faculty cannot detect cheating as well when they do not know their students' capabilities. Harper et al found that when staff received work which they thought had been outsourced, it was their knowledge of their students' abilities which raised the alarm.

The two most common indicators that raised their suspicions were: 1) due to their knowledge of the student's academic ability (70.6\%); and 2) due to their knowledge of the student's language ability (62.2\%). These findings align with this author's experience in Kuwait and in Saudi Arabia. Ghost-writing is most

(89) Bretag et al, the student survey, supra n10 at 9-10.

(90) Harper et al, the staff survey, supra n77 at 10-11.

(91) MacGregor, K and Stuebs, M “To Cheat or Not to Cheat: Rationalizing Academic Impropriety” (2012) Accounting Education 21(3) 265-287. 
obvious to a teacher when they know their students individually and when a piece of work is suddenly much better than what they have seen to date. A good practice is to set a piece of writing for students in the first days of class: it can be writing about themselves, their motivations for taking this class, their goals for the future and so forth. This becomes not only a way to get to know one's students but also a record of their language and writing ability.

Further in-class writing and speaking tasks (ungraded, formative assessment) can help the teacher learn the strengths and weaknesses of each student and refer weaker students on to access support. In terms of cheating detection, one needs to have a good understanding of the student's individual abilities in order to be able to detect contract cheating.

Fourth, there must be a system in place for systematically reporting all incidents of cheating to a centralized academic authority. Every faculty member should be requested to report each incident of suspected contract cheating to a central academic integrity decision-maker and that should be recorded in a central database. In that way, a unified approach can be applied as well as consistent, graduated penalties.

One of the biggest problems identified in the Australian research was that more than a third of faculty members deal with incidents of contract cheating themselves. When asked how they responded when they suspected contract cheating, 55.8\% referred it to an academic integrity decision-maker, $7.7 \%$ ignored it, and the remaining $36.5 \%$ dealt with it themselves. ${ }^{(92)}$ When asked what they do to deal with it, there were a range of responses: a warning/ counselling (41.9\%), zero for the assignment (37.1\%), and a reduced mark for the assignment (28.3\%) were the most popular.

This is not ideal: there is no way to keep track of which students are cheating, how often they are cheating, and in which subjects, if there is no requirement to report and no central database kept. Students who are repeat offenders might never be identified. The students might not ever be connected with appropriate student learning support or even disability support services if there is no centralized database. Problematic tasks and/or courses cannot be identified. Furthermore, there is no chance of consistency in terms of penalties between students across the institution if every lecturer is making their own individual decisions on how to deal with each instance of contract cheating. Consistency

(92) From personal experience, it is submitted that if this question were asked in Kuwait, a much higher percentage of faculty would probably report dealing with it themselves. 
is recommended as a key factor in achieving academic integrity. ${ }^{(93)}$ Therefore, it is strongly recommended that every institution must establish an "accessible, searchable and complete recordkeeping facility across the university". ${ }^{(94)}$ If there is a clear reporting requirement and a transparent mechanism for dealing with complaints, that will in turn lead to increased confidence from students that the university is dealing with cases of cheating in a consistent and fair manner. Fifth, universities must introduce compulsory courses/modules in academic honesty at all levels - undergraduate and postgraduate. Students must be explicitly taught about what the university defines as cheating, why it is forbidden and what will happen if students engage in academic misconduct. This is separate but related to point six below. Raising awareness about academic integrity with students and staff will per se help to prevent this type of conduct. The University of Sydney, which was badly affected in 2014-2015 by a cheating scandal, stated that "mandatory academic honesty education and an early focus on written communication skills" had to be embedded in all courses. ${ }^{(95)}$

Sixth, universities need to teach appropriate citation and footnoting conventions at the earliest possible time in a structured and research-informed manner, appropriate to the level of the student. This should ideally start in the later years of primary/elementary school (teaching students to write the name of the book or website from where they obtain information) and continue into high school (teaching students how to create a list of references, using quotation marks for direct quotes, etc). But at the very least, it must happen at the point at which students enter higher education.

Teaching proper ways to cite sources is essential because it is a learned skill - no one is born with an innate ability to properly cite sources. This is the institutions' responsibility. ${ }^{(96)}$ Studies have shown that one of the main reasons students plagiarize is because they do not understand scholarship

(93) See Thomas, J and Scott, J "UK Perspectives of Academic Integrity" in Bretag et al Handbook of Academic Integrity, supra $\mathrm{n} 23$ at 180.

(94) This is also Recommendation 3 in the University of Sydney's report, An Approach to Minimising Academic Misconduct and Plagiarism at the University of Sydney, Part 1: Prevention and Detection available at: https://www.smh.com.au/cqstatic/givnzv/Taskforce.pdf at 2.

(95) Ibid.

(96) It is interesting to see how the QAA's attitude on this has changed over the years from a detection/penalization approach to a teaching and learning approach. It has successively strengthened the wording in its Code of Practice to the point where the Code now requires that "Students are provided with opportunities to develop an understanding of, and the necessary skills to demonstrate, good academic practice": see the QAA's 2013 Code of Practice, chapter B6; see also Thomas and Scott, supra n94, at 168-170. 
and referencingrequirements. ${ }^{(97)}$ If students do not feel able to complete an assignment because they do not know how to carry out research or how to cite authorities, they are more likely to ask someone else to do it for them and thereby engage in contract cheating. Therefore, teaching research skills to avoid plagiarism is essential and this must be embedded at every level of the educational process.

There are plenty of resources available in this field and universities can also develop their own. ${ }^{(98)}$ Some universities, such as the University of Texas at Austin, have undertaken initiatives to teach students intervention strategies to help them help their peers. ${ }^{(99)}$ This sort of by-stander initiative may be another option - inviting students to help other students when they observe the conduct - which institutions can use to engage students in the process and raise awareness of the problem.

Seventh, the institution must convince their current and prospective student leaders to get on board with their academic integrity objectives. In the US, "honour codes" have been used for many years by the student body to spread a culture of academic integrity amongst students. There is research in the UK into their potential. ${ }^{(100)}$ The UK already has universities experimenting with a similar concept, an "academic value agreement". ${ }^{(101)}$ New York University has a branch campus in Abu Dhabi whose students have adopted a "community code". ${ }^{(102)}$ McCabe has reported that universities that use honour codes have lower rates of cheating than those which don't. He explains that this is due to the "student culture and university prioritizing of academic honesty" and not to the codes per se. ${ }^{(103)}$

The introduction of honour codes could be especially important in a country where corruption is a wider societal issue - when the campus culture must be

(97) Devlin and Gray supra $\mathrm{n} 83$ and the multiple studies cited there at 182-84 which all mention this factor.

(98) See for example Pecorari, D Teaching to avoid plagiarism: how to promote good source use (Maidenhead, Open University Press: 2013).

(99) US Federal News Service "University of Texas System Teaching College Students Intervention Strategies to Curb Sexual Assaults, Cheating, Suicide and Racism” 10 September 2015.

(100) Yakovchuk, N, Badge, J and Scott, J "Staff and student perspectives on the potential of honor codes in the UK" (2011) 7(2) International Journal for Educational Integrity 37-52.

(101) Dix, E L, Emery L F, and Le, B "Committed to the honour code: an investment model analysis of academic integrity” (2014) Social Psychology of Education 17(1) 179-196.

(102) Ibid.

(103) McCabe (2005) as discussed in Jones Roberts, C and Hai-Jew, S “An Online Course for Students Addressing Academic Dishonesty” (2009) 5(2) Journal of Online Teaching and Learning 182. 
strengthened to establish the principles that its members will uphold. The student council - and those running for council in student elections - must be convinced to promote the cause of academic integrity and take a leadership role because they have the power to influence the whole student body. Anecdotal evidence about experiences in Kuwait underlines this point: the author has been told privately that those seeking election to the student council at some institutions consider, as part of the election process, that they are "helping" students by distributing advertising materials regarding places where students can go to get "help".

They advertise the so-called "student service centres" (khidmat al-talib/makhtab al-talib) directly to students. This is done with both physical advertising and social media advertising. Since these student services centres are also offering contract cheating, this type of direct promotion must be halted. In its place, student leaders need to develop campaigns around promoting anti-plagiarism and anti-contract cheating practices on campus. If students can take the lead in promoting academic integrity, peer pressure on campus may help to prevent acts of contract cheating.

Finally, and building on the previous points, institutions need to make themselves aware of the extensive body of scholarly research that already exists into why, how, and how often students cheat. One of the recommendations in the final section of this paper relates to establishing an Academic Integrity Office on each campus. ${ }^{(104)}$ It is envisaged by this author that such an office could be charged with collating existing research on academic integrity to ensure that all proposed changes are research-informed.

In summary, universities need to be proactive and take steps in a number of different directions that will help create a culture of academic integrity on campus. To that end, universities ought to join the ICAI and participate in the annual International Day of Action Against Contract Cheating. Universities can get students involved in activities such as storytelling and debates to help raise awareness of the issue and how they should respond to approaches or opportunities to cheat. For example, the University of Wollongong in Dubai has participated each year. This has encouraged them to extend their activities to a "Week of Awareness Against Academic Misconduct." (105) They involve

(104) See below at "7. Recommendations".

(105) See for example Sundiata Post "UOWD Staff and Students Unite in the Fight Against Academic Misconduct" 28 January 2019, available at: https://sundiatapost.com/2019/01/28/uowd-staff-andstudents-unite-in-the-fight-against-academic-misconduct/. 
faculty who are award-winning researchers to share their experiences as well as students who have been approached online with cheating websites. ${ }^{(106)}$ Every university could consider organizing an annual awareness-raising event to open the doors to a discussion of contract cheating and to allow everyone to recognize openly that it exists, it is a challenge and that it needs to be tackled.

\section{The legal response: what governments can do to prevent contract cheating}

\subsection{New Zealand}

Governments can help universities to uphold academic integrity by considering criminalization of contract cheating. The two main questions that arise here are: 1) should the websites/student services centers who provide the product to students be held criminally liable for selling assignments; and 2) should students be held criminally liable for purchasing assignments? Adopting a legal approach to combat contract cheating should be seriously considered by every government because it targets the commercial entities who are supplying the product. Providers of the products know, or can reasonably be expected to know, that the customer who purchases an essay is likely to submit it, fraudulently, under their own name for course credits. This is especially the case when the student hands over the details of the assignment to the website/student services centre.

New Zealand was probably the first country in the world to criminalize contract cheating. In 2011, the Education Act 1989 was amended and section 292E was inserted. It provides as follows: ${ }^{(107)}$

\section{Section 292E Offence to provide or advertise cheating services}

(1)A person commits an offence if the person provides any service specified in subsection (4) with the intention of giving a student an unfair advantage over other students.

(2)A person commits an offence if the person advertises any service described in subsection (4) knowing that the service has or would have the effect of giving a student an unfair advantage over other students.

(106) Khan, Z “Going Beyond a Day to Become a Voice” ICAI Blog, 4 March 2019, available at: https:// academicintegrity.org/blog/going-beyond-a-day-to-become-a-voice/.

(107) Education Act 1989 (NZ) s 292E available at: http:/www.legislation.govt.nz/act/public/1989/0080/ latest/DLM3988805.html?search=sw_096be8ed81826902_292E_25_se\&p=1\&sr=2 (note: bold emphasis of the section heading is reproduced from the original legislation). 
(3)A person commits an offence who, without reasonable cause, publishes an advertisement for any service, described in subsection (4).

(4)The services referred to in subsections (1) to (3) are as follows:

(a) Completing an assignment or any other work that a student is required to complete as part of a programme or training scheme;

(b) Providing or arranging the provision of an assignment that a student is required to complete as part of a programme or training scheme;

(c) Providing or arranging the provision of answers for an examination that a student is required to sit as part of a programme or training scheme;

(d) Sitting an examination that a student is required to sit as part of a programme or training scheme or providing another person to sit the exam in place of the student.

Although existing criminal laws might have been sufficient (e.g. laws against fraud) the above provision was adopted to target contract cheating. The New Zealand law criminalizes various aspects of contract cheating, including exam impersonation (which was the subject of a scandal in Australia in 2015) ${ }^{(108)}$ and the selling of assignments. It focuses on the providers and the advertisers, but not the purchasers. The penalty for breaching $\mathrm{s} 292 \mathrm{E}$ is a fine of up to $\$ 10,000{ }^{(109)}$ That is not a significant enough deterrent given recent reports that ghostwriting can be a lucrative "side hustle" for students and even academics. ${ }^{(110)}$

It has been alleged that untenured academics (in the US) are writing whole $\mathrm{PhD}$ and LLM theses for a cost of around \$US30,000 for the former and \$US10,00015,000 for the latter. ${ }^{(111)}$ It is hard to assess the credibility of such claims, given that no academic is going to admit to having been involved in such a serious

(108) For an interesting introduction to the exam impersonation scandal, see the documentary SBS "Pens for Hire (The Feed)" 10 November 2015 available at: https://www.sbs.com.au/ondemand/ video/563219523562/pens-for-hire-the-feed.

(109) Education Act 1989 (NZ) s 292E (2).

(110) Anonymous, "Academia's grey markets offer rich pickings for the untenured" Times Higher Education News 7 March 2019 available at: https:/www.timeshighereducation.com/opinion/academiasgrey-markets-offer-rich-pickings-untenured.

(111) Ibid. 
act of misconduct, but if they are true - and there are similar reports that this is happening in the UK ${ }^{(112)}$ which seems to corroborate the US stories - then a fine of up to $\$ 10,000$ is not going to have a deterrent effect. If the New Zealand legislation is adopted in other jurisdictions, it is suggested that a much higher fine, perhaps around the $\$$ US100,000 mark, would be more appropriate, as well as a custodial sentence. If the fine is too small, then, in the words of Draper and Newton, it will be nothing more than a "running cost for a large company". ${ }^{(113)}$

To date, s 292 of the Education Act (NZ) has been discussed by the courts only once - in the context of the Assignment 4 U cheating scandal. ${ }^{(114)}$ A company with a physical office in Auckland was offering tutoring and counselling services to international (Chinese) students studying in New Zealand. Tutoring was just a front - the business was actually writing and selling tailor-made assignments. The company was called "Assignment4U" and it was operating both an office and a website.

At the time that the story broke in 2013, it was unclear how many students had purchased assignments, but the business had been in operation for at least five years, and the offending preceded the passing of s 292E. The "tutors" who wrote the assignments were based both in New Zealand and overseas and they claimed to offer services up to $\mathrm{PhD}$ level. ${ }^{(115)} \mathrm{In}$ response to the police allegations that Assignment4U was in the business of offering "cheating services", the business said they only provided "model answers" to be used as study aids - not to be submitted as assignments. ${ }^{(116)}$

They also said that they posted a notice stating that the assignments were only to be used as "study aids" but the Police Commissioner said such a notice was a "sham". (117) The court was told how students would provide the assignment question, the word limit, sometimes the relevant textbooks and the deadline.

(112) For instance, see Morgan, J "Website offers 'complete PhD service’ for £36” Times Higher Education 24 January 2019, available at: https://www.timeshighereducation.com/news/website-offerscomplete-phd-service-36-thousand-pounds.

(113) Draper and Newton, supra n 69.

(114) Van Beynan, M, Lee, F and Dudding, A "Chinese cheats rort New Zealand universities with fakes" Stuff News 12 Mary 2013, available at: http://www.stuff.co.nz/national/education/8662224/Chinesecheats-rort-NZ-universities-with-fakes.

(115) Ibid.

(116) Commissioner of Police v Li [2018] NZHC 1566 [27 June 2018] available at: https://forms. justice.govt.nz/search/Documents/pdf/jdo/44/alfresco/service/api/node/content/workspace/ SpacesStore/17cda54e-0c71-45cc-a2d1-e07f0de53dfd/17cda54e-0c71-45cc-a2d1-e07f0de53dfd.pdf.

(117) Ibid, para 9. 
The fee was set in accordance with the word limit, the type of grade that the student wanted to achieve and the timeframe. Then Assignment4U would have one of their writers create the assignment; when it was ready it was handed to the student who submitted it. The police estimated that 11,549 assignments were sold at an average price of $\$ 406.81$ per assignment. The business made an unlawful benefit of $\$ 4,698,000$ from $2006-2013 .^{(118)}$ No one was criminally prosecuted in the Assignment $4 \mathrm{U}$ case because the Police considered it was more effective to pursue the company's property and seek its forfeiture as proceeds of crime.

The Commissioner of Police made an application to the court under the Criminal Proceeds (Recovery) Act 1989 to obtain a court order for the forced sale of assets that belonged to the company's directors. Thus, although s 292E was an option, the Police felt that the best way to punish this company was not to pursue a s 292E prosecution but to obtain the assets purchased with the crime of selling assignments. A settlement was reached with the defendants. The exact amount of the settlement was not disclosed. However, it was most likely in the realm of $\$ N Z 2,210,000(\mathrm{KD} 458,000)$. The sum was paid through asset forfeiture orders.

This case is a good example of the power of legislation to deal with contract cheating. The actual offence under s 292E was not used, but because it existed, it helped the Police to gain orders for property of a significant value. If companies know that they can be criminally prosecuted - and they might lose all their profits - it may well deter them from engaging in the business of offering cheating services to students.

In a country such as Kuwait-where contract cheating occurs "out in the open" via student service centres (khidmat al-talibi) - it could be very effective to criminalize the act of writing assignments for students. The student service centres could still offer photocopying and typing services but if they moved into the area of writing assignments then they would risk criminal prosecution. Undercover "sting" operations could easily be used in Kuwait as they have been used in New Zealand and elsewhere to monitor whether assignments were being purchased. In addition, other penalties could flow from a conviction.

For instance, if the writers of the essays are foreign nationals - as they almost certainly are - they could be required to leave Kuwait and be returned to their country of origin once they are found to have committed a criminal offence. That penalty, once exacted on a few individuals, could serve to help stamp

(118) Ibid, para 18. 
out the practice. It might drive students to go to websites instead and this underlines the need for both a preventative/teaching and learning approach as well as a criminal approach.

\section{The pros and cons of the New Zealand legislative approach}

The positive aspects of New Zealand's legislation are that it criminalizes any offering or advertising of cheating services and this, per se, must surely act as a deterrent-to some degree-to anyone who might be considering offering such a service. Although it focuses on the supply-side of commercial contractcheating, it is argued here that the criminal penalty also perhaps acts as a deterrent to students: although it does not criminalize the student for purchasing the service, it may make students think twice whether they want to engage in criminal conduct by purchasing an assignment. ${ }^{(119)}$

For the legislative deterrent to work, it is submitted here that universities would need to make it very clear to students that if they are proven to have been involved in any breaches of this law they might well escape criminal prosecution, but their actions would be recorded against them by the university and it may have a negative effect on their efforts to be admitted into certain professions (e.g. law) which place a strong emphasis on honesty and trustworthiness. In addition, it might mean that they would be ineligible to gain references from academic staff at that university for future jobs and scholarships.

If those university-based penalties were put in place, and consistently applied, that might well strengthen the hand of universities in trying to combat contract cheating, without going so far as to prosecute students (discussed below).

One negative aspect of the New Zealand legislation is the fact that s 292E is only concerned with cheating apropos of students: it does not seem to affect purchasers who are not students, for instance, cheating by academics, which is probably also occurring. Times Higher Education reports that some academics pay for their journal articles or conference papers to be written for them. ${ }^{(120)}$

(119) This is an argument put forward by the writer that requires further research. To date, the author has not seen a survey question which asks students whether criminalizing the selling of assignments would discourage them from buying.

(120) This allegation is found in, for example, Anonymous, "Academia's grey markets offer rich pickings for the untenured" supra n110, where the author claims that: "Some more capable adjuncts supplement their incomes by writing conference papers for colleagues on the tenure track, earning about $\$ 10,000$. Many of these papers are subject to no formal quality review if you know the conference organizers...But it is journal papers that are the bread and butter of the shadow professoriate. Universities worldwide increasingly require staff to publish several papers a year...If you bought your 
That is certainly a serious breach of academic integrity but it would not be penalized under s 292E since there is no student involved in the transaction. Cheating or breaches of academic integrity by academics, whilst they are serious and certainly occur, is not the focus of the current paper so this is merely mentioned in passing. However, if a government wanted to draft a comprehensive provision, they ought to consider penalizing academics, and not just students, for contract cheating.

Another negative aspect of s 292E is that it requires intention. The prosecutor would have to prove, beyond reasonable doubt, that the provider intended to give the student an unfair advantage. Many websites have a "disclaimer" on them which usually says that the essay (or other product) is not to be submitted to a university, and that it is being provided for research purposes only. Edubirdie - a website that offers ghost-writing services - states in its "terms and conditions" that neither it, nor its partners, will be liable for "any inappropriate, illegal, unethical, or otherwise wrongful use of the products and/or other written material received from Writers." ${ }^{(121)}$ They appear to aware of the possible outcomes since they specifically mention that they will not be responsible for "plagiarism, expulsion, academic probation, loss of scholarships/titles/awards/ grants, positions, lawsuits, poor grading, failure, suspension...". ${ }^{(122)}$ They might argue that they never intended the student to submit the work for credit. One way around this is to draft a law which allows prosecutions to succeed based on what the defendant ought reasonably to have known.

So, if the website is advertising that it can provide plagiarism-free papers, within any deadline, and the student states their required grade, it can be inferred that they ought reasonably to have known it was going to be submitted for course credits. ${ }^{(123)}$ Draper and Newton have taken it a step further: they examined New Zealand's approach and suggested their own solution based on strict liability. ${ }^{(124)}$

In their suggested legislative response, they shift the burden of intent from the police (having to prove intent by the company) to the company (who is presumed to have intent, and the defendant has to prove they couldn't have

doctoral dissertation and struggle with your teaching and administration loads, you will never be able to produce original research. But $\$ 15,000$ will get around that problem."

(121) EduBirdie “Terms and Conditions", updated 25 July 2018, available at: https://edubirdie.com/terms. (122) Ibid.

(123) Newton, P and Lang, C “Custom Essay-Writers, Freelancers and other Third Parties” chapter 19 in Bretag Handbook of Academic Integrity, supra n23.

(124) Draper and Newton supra n69. 
known the assignment would have been used by the customer for course credits). ${ }^{(125)}$ Anyone interested in a legislative response would be remiss not to consider Draper and Newton's proposed solution. ${ }^{(126)}$

\section{Should students be criminally prosecuted for contract cheating?}

Any market is driven by supply and demand. The NZ law focuses on those parties supplying the product but should those driving the demand-the studentsalso be criminally responsible for their actions? The deterrent factor that is inherent in the New Zealand law would obviously be increased if students were also criminally penalized but it is argued here that that is a step too far. It is this author's view that students should not gain a criminal conviction for purchasing an assignment, but the university should be advised by the police of successful prosecutions, and institutions should be made aware when their students were involved in a prosecution to the extent that that is possible.

Where a student is implicated and their role is clear, the university ought to have in place procedures for disciplining that student-even if the student was not subjected to a criminal prosecution. The university ought to consider suspending or expelling students who have purchased work and submitted it as their own (see section 5 below). But it is probably going too far to criminalize the student. It is a finely balanced point.

It is easy to understand the perspective of academics who support criminalization of both suppliers and student purchasers: it "takes two to tango" and it is the students who are buying and then choosing to submit the work as their own. But if students were prosecuted, perhaps academics would become reluctant to report suspected acts of contract cheating knowing that their reporting was potentially exposing the student to prosecution.

This may make the teaching and learning solutions harder to implement (and may erode the trust placed in teachers by their students) because the criminal sanction would take precedence over any other possible sanction in terms of seriousness. Having to report students who have purchased their assignments to the police would take universities in a very unusual, and it is submitted unwelcome, direction.

(125) Ibid.

(126) Ibid at "Table 1" where they set out their proposed wording. Section 1 of their proposed law begins as follows: "(1) A person commits an offence if the person provides any service specified in subsection (4)... (2) A person commits an offence if the person advertises any services specified in subsection (4)...(4) The services are...(a) completing in whole or in part an assignment...or any other work that a student enrolled at a Higher Education provider is required to complete as part of a Higher Education course..." 
Although it is the author's current view that students should not be criminalized whilst providers should be, it is acknowledged that this may not reflect the opinion of other academics. For instance, Times Higher Education recently conducted a survey in which 230 participants responded. ${ }^{(127)}$ Of those, $84 \%$ were in favour of criminalizing the service providers and $41 \%$ were in favour of also criminalizing students. ${ }^{(128)}$

That was not a rigorous survey, since it was small, and the respondents were self-selecting. The survey has also attracted some valid criticism. ${ }^{(129)}$ Nevertheless, it appears to show that there is a great deal of support in the academic community for governments to step in and criminalize contract cheating because universities alone cannot stop the demand or the supply.

The academic support for criminalization has also been recently reported in more rigorous research, conducted by Newton and Awdry. ${ }^{(130)}$ They conducted a survey of staff at universities in Australia and the UK to better understand staff attitudes towards commercial contract cheating (note that they did not include cheating when the provider was a family member or friend, they were only concerned with commercial contract cheating). Their research aimed to fill a gap in the literature: there is much written about why students cheat, and how to prevent this, and there is literature on the suppliers of the cheating services, but there is relatively little on staff attitudes towards contract cheating. Newton and Awdry point out, quite rightly in this author's opinion, that: ${ }^{(131)}$

It is critically important to gather staff perceptions of contract cheating... because staff are...tasked with attempting to detect any instances of contract cheating in the first place, determining relevant outcomes for those caught cheating and designing assignments to

(127) McKie, A “Many University staff back prosecuting students over essay mills" Times Higher Education 7 March 2019, available at: https://www.timeshighereducation.com/news/university-staff-backprosecuting-students-who-use-essay-mills.

(128) Ibid.

(129) Ibid, see the comments listed underneath the main post. Some comments criticize the survey on the basis that academics are hypocritical because many of them are the ones doing the writing (according to the post's author), whilst others criticized it because the respondents were probably guilty of selective bias since only academics who are in favour of criminalization would likely choise to respond. That is a small sample of the criticism.

(130) Newton, P and Awdry, R "Staff views on commercial contract cheating in higher education: a survey study in Australia and the UK" (2019) Higher Education published online Feb 2019, 1 [hereinafter Newton and Awdry]. Note that the Newton and Awdry article does not have page numbers listed in the online publication, therefore, no official page numbers are referred to when attempting pin-point references.

(131) Ibid. 
encourage engagement and dissuade cheating behavior. Staff see this behavior 'on the ground', and so have, as a fundamental stakeholder group, a unique insight into why it might be happening.

Newton and Awdry designed a survey for staff and then gained responses through an online survey tool called "Limesurvey". They received 196 completed survey responses ( $78 \%$ from Australia and 22\% from the UK). Their findings are very interesting and they may be (imperfectly and briefly) summarized as follows. On average, staff thought that $10.3 \%$ of students used ghost-writing services for assignments (although responses ranged from 0 to 50\%). When asked if they had ever been personally aware that one of their students used these services, $41.8 \%$ said "yes" and when asked if their institution had ever caught a student using one of these service, 59.7\% reported "yes". (132)

Regarding penalties when a claim of contract cheating was proven, the staff reported mainly serious penalties: most failed the module/unit, some failed the assignment, were suspended or expelled and there were three reports of a degree being revoked. At the other end of the spectrum, one staff member reported that just a warning was given. ${ }^{(133)}$ This research may be contrasted with the findings in Bretag (2018) in which 1147 staff across 8 Australian universities responded. On this question of penalties, Bretag et al found that $55.8 \%$ of respondents referred the matter to an academic integrity decision maker (i.e. 332 out of 595). A further $7.7 \%$ reportedly ignored it. The remaining respondents handled the penalties themselves and they included providing a warning or counselling $(9.2 \%)$, asking the student to resubmit (6.7\%), applying a penalty to the assignment mark (5.9\%), failing the student in the assignment or subject (4.7\%), or referring the student to learning advice (2.2\%). We note that Bretag et al did not ask their survey participants about their attitudes towards criminalization.

Returning to the issue of criminal penalties, Newton and Awdry specifically asked respondents to consider the criminalization of students and essay mills/ contract cheating websites. As for the former, survey participants were asked to rate their agreement -on a 5-point Likert scale- with this statement: "A student who purchases an essay that has been written by someone else and then submits it as if it were their own is committing an act that should be illegal." They were also asked to rate their agreement with this statement: "A 
company that sells an essay knowing that a student intends to submit it as if it is their own, is committing an act that should be illegal." The majority of respondents agreed with both statements, but they more strongly with the latter one concerning the companies that provide the essays. ${ }^{(134)}$ In addition, 18 freetext comments were posted, and six of these argued against the criminalization of students for purchasing essays. Reasons given for not criminalizing students included the fact that "universities are educational institutions not correctional facilities", that the focus should be on preventing this conduct and resolving the motivations, and that criminalization wouldn't work. ${ }^{(135)}$

\section{Aside from New Zealand, who else is criminalizing contract cheating?}

Aside from New Zealand, some states in the US have criminalized contract cheating or criminal penalties already exist for broadly worded crimes such as "mail fraud". Other countries have been looking at New Zealand's legislative response and may soon follow suit. The UK is considering New Zealand's legislative response. ${ }^{(136)}$ Academics have also put forward possible legislation that could be adopted by governments. The Council of Europe has recently considered New Zealand's legislation, as has the QAA. ${ }^{(137)}$

In summary, it is predicted that we are witnessing the beginning of a trend towards the criminalization of contract cheating services. It began in New Zealand but it is this author's contention that before long, many governments will take steps to criminalize the providers of commercial contract services. In the meantime, it is recommended that all governments should proactively consider this question and should open a societal debate over whether it ought to be illegal for any person, website, or office to create material for students when there is a reasonable expectation that the material could be submitted as part of a course, admissions application or for any form of course credits/grades.

Universities need help in the battle against contract cheating and therefore governments must step in with a legislative response. In some countries,

(134) Ibid at 10.

(135) Ibid at 11.

(136) See Newton and Awdry, supra n131.

(137) The Council of Europe is currently working on solutions. To that end, see the proceedings of the $2^{\text {nd }}$ Plenary Meeting of the Council of Europe Platform on Ethics, Transparency and Integrity in Education (ETINED), 15-16 February 2018, programme and links to presentations available at: https:// rm.coe.int/etined-2018-programme-and-powerpoints/16808aa93f. 
like Kuwait, many students would likely approach a student service offering assignments in a face-to-face setting, so it should be relatively easy to locate the targets and prosecute them if they insist on continuing. This would probably drive some students to seek the services online. This brings to mind the recent comments of Tim Berners-Lee, the inventor of the internet. BernersLee noted on 12 March 2019 - the $30^{\text {th }}$ anniversary of his invention - that the internet has become a place for scammers and he called upon governments around the world to crack down on the problems, saying that it would be "defeatist" not to. ${ }^{(138)}$

The use of the internet to facilitate commercial contract cheating is one such area where the websites are scamming universities and non-cheating students (and society at large, arguably), and it is contended that this is precisely one area where governments can, and should, catch up: they need to legislate to help universities protect the integrity of their degrees and stamp out what is essentially fraudulent conduct.

\section{What can quality assurance agencies do to prevent and combat contract cheating?}

Promoting academic integrity needs to come from the top: that means the top administration within universities but also from those entities that oversee all institutions - the quality assurance and accreditation agencies. ${ }^{(139)}$ Quality assurance agencies obviously have a stake in the academic integrity of individual institutions, and the academic integrity of the higher education system as a whole.

Every national (and international) accreditation agency needs to establish a working group or a committee that is dedicated to understanding the current practices and problems regarding contract cheating in the institutions for which they are responsible. The UK's main quality assurance provider has been very active in this area. The Quality Assurance Agency (QAA) has produced two recent reports on this problem and many of the suggestions in their 2017 report should be closely considered by other countries' accreditation agencies as well as by

(138) Collins, $\mathrm{T}^{\text {"The }} 30^{\text {th }}$ anniversary of the World Wide Web: Inventor Tim Berners-Lee calls for people to come together and to stop abuse of the internet" Daily Mail 12 March 2019 available at: https://www.dailymail.co.uk/sciencetech/article-6796403/Tim-Berners-Lee-calls-people-come-stop-abuse-internet.html.

(139) See Gallant, T B and Drinnan, P “Organizational Theory and Student Cheating: Explanation, Responses and Strategy" (2006) 77(5) The Journal of Higher Education 839-860 at 855, available at: https://www.tandfonline.com/doi/abs/10.1080/00221546.2006.11778946. 
individual institutions. ${ }^{(140)}$ The QAA suggests in its 2017 report that there are five key areas where change should be implemented to combat contract cheating:(141)

- education (information and support for students);

- education (training and information for staff);

- prevention;

- detection; and

- regulations and policies.

Quality assurance agencies need to work with all the institutions in their area to open a conversation that seeks to identify the current problems and practices regarding contract cheating across all campuses. They need to then design and carry out sector-wide research - of staff and students - to determine whether existing policies and practices are sufficient to combat contract cheating.

Secondly, using their commissioned research as well as international research, they need to provide guidelines on best practice to institutions. For example, they ought to offer guidance on best practice for assessment design to minimize opportunities for student cheating. This will also be done by individual institutions, but the national accreditation agency is uniquely situated to be able to draw from all institutions and provide advice and guidance to all institutions. They can also offer model academic integrity policies, to support institutions in their move towards greater awareness of academic integrity on campus.

Thirdly, they can use their standing to create formal standards and guidelines for all institutions to aspire to. Having clear standards around academic integrity practices will help each individual institution improve their practices and policies. Tying that to the cyclical accreditation process will further incentivize institutions to strengthen what they are already doing. Only a national/international quality assurance provider has the clout to force institutions to recognize the problems in their midst and encourage them to make changes that will help to educate, prevent, detect and manage incidents of contract cheating.

Fourthly, they can look to Ireland as an example of how the government can empower a national accreditation agency if it chooses to. In 2018, Ireland introduced a bill to strengthen the role of its national agency, Quality and Qualifications Ireland (QQI). Amongst many important measures in the new law, there is a provision which will "provide QQI with statutory powers to

(140) QAA, 2017 Report, supra n 74.

(141) Ibid. 
prosecute 'essay mills' and other forms of contract cheating."(142)

Finally, quality assurance agencies can have an impact on ensuring that consistent contract cheating policies are followed across all institutions. They can also support institutions to adopt consistent penalties both between students at an institution and between institutions. Consistency of penalties has been identified in the literature as being very important to academic integrity. ${ }^{(143)}$ The UK's AMBeR Project (Academic Misconduct Benchmarking Research Project), which concerned penalties for plagiarism in $168 \mathrm{UK}$ institutions, could be used as an example of the type of national research on contract cheating penalties that could be undertaken by individual quality assurance entities. ${ }^{(144)}$

It is predicted that such a research project would likely expose a great deal of inconsistency within institutions, and between institutions, on penalties for contract cheating. A quality assurance or accreditation agency can sponsor research and recommend uniformity in this area so that institutions are both less open to challenge and fairness can be achieved for all students.

\section{Recommendations}

This section draws upon, inter alia, the above discussion, published research, university websites, accreditation agencies' reports and personal experience. It offers a "check-list" of things that can be done to combat the contract cheating phenomena and the list is targeted at higher education institutions. It should be read in conjunction with sections 4,5 and 6 above as it builds upon the analysis provided there. It is hoped that the following list could be useful to all higher education providers, here in Kuwait, but also elsewhere, to ensure that they are doing everything possible to prevent contract cheating and to secure for their staff and students a culture of academic integrity on campus.

As mentioned above, solving the contract cheating problem requires a multipronged approach but it is important to approach it with the mind-set that

(142) MerrionStreet.ie Irish Government News Service "Minister Mitchell O'Connor announces the publication of Qualifications and Quality Assurance (Education and Training) Amendment Bill" 20 July 2018, available at: https://merrionstreet.ie/en/News-Room/Releases/Minister_Mitchell_O'Connor_ announces_the_publication_of_the_Qualifications_and_Quality_Assurance_Education_and_Training_Amendment_Bill.html.

(143) Thomas and Scott, supra n 94 at 180-81.

(144) Tennant, P and Duggan, F “Academic Misconduct Benchmarking Research Project Part II: The Recorded Incidence of Student Plagiarism and the Penalties Applied” May 2008, available to download from here: https://www.plagiarism.org/paper/academic-misconduct-benchmarking-research-project-part-2. 
there is no single solution., It must be borne in mind that the lessons students learn at university - including ethical attitudes and practices - will ultimately be transported with them to their future workplaces or other educational institutions. Therefore, the effects of these recommendations could be wideranging, temporally and spatially.

1. Act now: Don't wait for a scandal to occur involving your institution. Once there is a cheating scandal, an institution's reputation will be immediately, publicly and possibly permanently, damaged; it may be very difficult to recover the trust of stakeholders. ${ }^{(145)}$

2. Start a conversation: Open up a discussion involving faculty, students and administrators about the need to establish a "culture of academic integrity" on campus. Discuss with faculty—individually, in small groups or as a whole-whether they have ever received work from students which they suspected had been outsourced. Determine if there is an existing problem (there will be, in light of Australian, UK and NZ research.) ${ }^{(146)}$

3. Academic Integrity Office: Establish an Academic Integrity Office/ Unit or similar entity to act as a liaison and co-ordinator for staff and students. ${ }^{(147)}$ It is important to ensure that the focus is not just on

(145) For instance, Australia was rocked by several cheating scandals in 2013-2015 including the MyMaster ghostwriting scandal. Reports suggest that approximately 1,000 students were involved in the MyMaster scandal including ghostwriting of assignments and exam impersonation: see McNeilage, A and Visentin, L "Students enlist MyMaster website to write essays, assignments" Sydney Morning Herald 12 November 2014, available at: https://www.smh.com.au/education/students-enlist-mymaster-website-to-write-essays-assignments-20141110-11k0xg.html. A 30-year-old Chinese woman was the sole director of the company MyMaster Group Pty Ltd behind the website. One request, according to McNeilage and Visentin, was for "a 6,000-word essay for a human rights law course at the University of NSW, which was worth $70 \%$ of the student's overall grade." Some students paid multiple times, one student had paid for six assignments, another student had paid for eight. There was huge concern about how this scandal would impact on reputation, funding and future enrollments. The university most affected was the University of Sydney: cheating was spread across multiple faculties and 37 courses were affected (McNeilage and Visentin). Ultimately this scandal led to many changes in assessment and detection. To see how the University of Sydney reacted, see their report into academic misconduct: University of Sydney, An Approach to Minimising Academic Misconduct, supra $\mathrm{n} 95$.

(146) See Newton and Awdry supra $\mathrm{n} 131$ as well as Bretag et al, the student survey, supra $\mathrm{n} 10$ and Harper et al, the staff survey, supra $\mathrm{n} 77$.

(147) The University of Sydney was faced with a cheating scandal in around 2015 and it set up a "Cheating Task Force" which aimed to determine how many students were cheating and how they were getting away with it. For more information on how that university dealt with a cheating problem, see the docu- $=$ 
creating the office in name, with a label on the door and a tab on the website, but that it is headed by a person/people who is/are qualified in teaching and learning pedagogy, who can co-ordinate research projects to drive your institution towards embracing a culture of academic integrity, and who can collaborate with your teaching and learning centre on assessment and curriculum design.

4. Policy: Task the Academic Integrity Office with creating an Academic Integrity Policy, with input from students, staff, administrators and other stakeholders. Give it a wide-ranging mandate to encompass all aspects of academic integrity on campus.

5. Focus groups: in order to change attitudes and behaviours, one must first understand them, according to psychologists, so the Academic Integrity Office should organise focus groups to ask students and staff about their attitudes and behaviours towards contract cheating. ${ }^{(148)}$

6. Research and surveys: Task your Academic Integrity Office with designing and carrying out research, of staff, students and administrators, into all aspects of academic integrity. Baseline research is needed so that any changes can be later tested to see whether they have brought about change. The following areas could be the subject of research projects:

a. Conducting research of staff and students about current attitudes towards cheating and staff's ability to detect it; ${ }^{(149)}$

b. Conducting anonymous self-reporting research into students' current practices around cheating, such as where they obtain their paid-for assignments, how often they obtain them and why they obtain them. Such surveys have their limitations.

$=$ mentary by SBS, "Pens for Hire" available at: https://www.sbs.com.au/ondemand/video/563219523562/ pens-for-hire-the-feed. The University of Sydney set forth a series of recommendations after the scandal, recommendation 4 was to "establish an office of educational integrity...to provide a single point of contact at the University for matters relating to academic misconduct in coursework...": see the University of Sydney, An Approach to Minimising Academic Misconduct, supra n95.

(148) Focus group work in relation to plagiarism could be a guide here: see Gullifer, J and Tyson, G A "Exploring university students' perceptions of plagiarism: a focus group study" (2010) Studies in Higher Education 35(4) 463-481 at 464 DOI: 10.1080/03075070903096508.

(149) Note that Newton and Awdry argued there is a strong need to survey staff since they see contract cheating "on the ground" and they will also be ones to have to implement any changes in assessment design: supra $\mathrm{n} 131$. 
7. Definitions: Have your Academic Integrity Office work with a range of faculty members from all ranks to arrive at agreed definitions and understandings of what academic integrity means and what amounts to contract cheating, among other things. ${ }^{(150)}$

8. Mission statement and values: consider amending your institution's mission statement and/or values to reflect your institution's commitment to academic integrity.

9. Educate staff and students: Use the results of research to respond - then design a programme to educate staff and students about all aspects of academic integrity including the problem of contract cheating and what, generally speaking, is ethical behaviour on campus. ${ }^{(151)}$

10. Database: Establish a database encompassing the entire institution for all complaints about all types of student cheating and ensure that the database is used to keep an accurate record - of complaints that were substantiated and those that were not - as well as the penalties that were handed down. This will help to detect which students are the most vulnerable; it may help to determine which courses experience the most cheating and which assessment tasks need redesigning.

11. Penalties: establish set penalties for first breach, second breach etc. of contract cheating policy. Ensure students are aware of the penalties. Consider notifying national bodies - such as the law society - when students are found "guilty" of having engaged in academic dishonesty.

12. Disciplinary Committee: Establish a Disciplinary Committee to consider complaints, penalties and appeals in accordance with written policy - this should relate to staff, students and administrators' conduct - in a process which is transparent and consistent. As per above, penalties must be consistent across the institution and must be recorded in a centralized record.

13. Honour Code: Work with students to establish an Honour Code and

(150) Newton and Awdry note that: "without shared agreement on the definitions, seriousness and elements of academic integrity and misconduct policies, educational practice to enhance integrity and minimize misconduct are unlikely to succeed": supra n131 at 3, citing the findings of Brimble and Stevenson-Clark (2005) and Wilkinson (2009).

(151) The work of the QAA is useful to consult here, see QAA 2017 Report, supra n74. 
help students to embed a culture of academic integrity within the student body. Encourage your students to champion the drive towards academic integrity.

14. Academic honesty education: Introduce mandatory academic honesty education. ${ }^{(152)}$ Every undergraduate and postgraduate programme should have a compulsory course/module for first-year students to:

a. Educate them on practices of academic honesty and ethics;

b. Clearly define for them the types of conduct which are unacceptable;

c. Explain why those practices are unacceptable; and

d. To clearly define the penalties that will follow from engaging in academic misconduct.

This is absolutely essential in a university which teaches courses such as law, where the graduates are expected to have impeccable personal attributes once they join their profession. Begin in first year, but ensure that there is ongoing academic honesty education.

15. Teach citation techniques: as mentioned above at section 4 , students are more likely to outsource their work if they do not know how to cite their sources correctly. This is common sense: if a student doesn't know how to create or format footnotes and a bibliography, they are likely to pay someone to do it for them. These skills of scholarship must be taught to students at all levels within the higher education institution.

16. Teach students computer skills, specifically, how to create and edit Word documents and PowerPoint presentations: if students are not confident using computers to create their own documents and presentations, they are more likely to outsource their work. Each institution must ensure that their students have the technical computer skills that they need to create their own work.

17. Enhanced detection: Academic honesty education works best when

(152) The University of Sydney placed this as their first recommendation in their taskforce report into academic misconduct: supra $\mathrm{n} 95$. 
it is combined with enhanced detection. ${ }^{(153)}$ Therefore, it is useful to consider using plagiarism detection software, but this decision has to be taken carefully. Contract cheating is different from plagiarism. Many universities use "Turnitin" for detecting plagiarism, and that may be useful, since it has been shown that companies sometimes resell work (or post it online if there is a disagreement with their customer over payment). ${ }^{(154)}$ However, there are also concerns in having students turn over all their intellectual property to a private company. ${ }^{(155)}$ Turnitin will likely not detect contract cheating.

18. Social media: Ask your IT department to constantly monitor all your institution's social media channels to determine whether your students are being directly targeted with advertising and/or messages from potential contract cheating companies. Take measures to block such advertisers. Ask students to notify your university's administration when they notice such direct advertising and give them an incentive to be proactive in this area.

19. Tutoring services: There will always be some students who use tutoring services outside of the institution. Investigate the extent to which your students are using private tutoring services. These are often a front for contract cheating and evidence shows that there is a fine line between genuine "tutoring" and writing assignments for students. ${ }^{(156)}$ Make sure students understand where that line is and the problems of crossing it. Discourage students from seeking private tutoring services.

(153) The University of Sydney Taskforce Report: “Academic dishonesty is most effectively addressed through the application of both education strategies and detection measures (Owens and White, 2013)" supra n95 at 2.

(154) Universities New Zealand, "We need to talk about cheating" supra n2.

(155) This research does not wholeheartedly endorse the use of Turnitin as a means to deter contract cheating, for two reasons. First, because commercial ghost-writing is probably not going to be detected by plagiarism-checking software. Secondly, because Turnitin is a powerful company, it has a monopoly, students have no choice in whether to use it and it owns every student's intellectual property. For a brief discussion of the latter point, see McKie, A “£1.3 billion Turnitin sale spotlights intellectual property fears" Times Higher Education, 11 March 2019 available at: https://www. timeshighereducation.com/news/ps13-billion-turnitin-sale-spotlights-intellectual-property-fears.

(156) In Australia, the MyMaster website was being used by students to obtain assignments. The sole director of the company that operated that website was Ms Yingying Dou. She was also the sole director of a tutoring services company called Yingcredible. Both MyMaster and Yingyingcredible were registered to the same principal place of business: see McNeilage and Visentin, supra n145. 
20. Secondary school education: Reach out to secondary schools and work with your Ministry of Education to help prevent cheating in secondary schools. Research shows that most students who cheat at university reported that they had cheated at school. ${ }^{(157)}$ The Harvard study also showed that students had cheated on exams prior to attending Harvard. ${ }^{(158)}$ Preventing academic misconduct early with education is better than penalising it in higher education after it has become a habit.

21. Accreditation and quality assurance: Work with the national accreditation agency in your country to design research projects that seek to understand, in a cross-institutional manner, how and why students cheat, and then collaborate on designing effective teaching and learning practices from which all institutions can benefit. Work with your accreditation/quality assurance agency on campus to collaborate on anti-contract cheating initiatives.

22. International connections: Encourage your institution to become a member of the International Centre for Academic Integrity (ICAI).

23. International Day Against Contract Cheating: Get your institution involved in the ICAI's "International Day Against Contract Cheating", to be held this year on 19 October 2019. In 2018, only 8 institutions participated from Africa and the Middle East. Make it an annual event to create awareness among students, faculty and administrators. Download the ICAI's resources and get the Student Council involved.

24. Lobby your Minister of Higher Education: in the UK, 40 universities' bosses wrote to the universities minister, Sam Gyimah, in 2018 urging the government to ban essay-writing companies. ${ }^{(159)}$ University bosses in every country should consider joining together and adopting the same direct approach.

25. Legislative change: Universities and quality assurers can join together to lobby their government and ask it to consider a

(157) See Christensen-Hughes and McCabe "Academic misconduct within higher education in Canada" $s u$ pra $\mathrm{n} 4$ at 3, citing research by Davis (1992). They cited therein a US study in which $99 \%$ of students who cheated at university had cheated at high school.

(158) Moya-Smith, supra $\mathrm{n} 8$.

(159) Smith, K "University bosses call for ban on essay-writing companies" BBC News, 27 September 2018, available at: https://www.bbc.com/news/education-45640236. 
legislative response: the criminalisation of companies/websites/ student service centres that provide the material to students will help to reduce the supply side of the equation. At the moment, those who supply the assignments may be operating openly but if their conduct is criminalised they will find it harder to attract customers; students may also be reluctant to use their services once criminalised for fear of disciplinary proceedings or impacts on their future professional standing. ${ }^{(160)}$

\section{Conclusion}

The first step in solving any problem is to face up to the fact that it exists: every institution needs to acknowledge that contract cheating is currently happening on their campus. Every university needs to accept that some of their students are purchasing work or asking friends/family members to complete assignments and then their students are submitting it to their lecturers for course credits. Those facts are certain. The uncertainties are that administrators and faculty probably do not know which students are engaging in it, how prevalent is the practice, how to detect it and - most importantly - how they can stop students from resorting to purchasing their assignments.

Every higher education institution will be aware of how much damage contract cheating is capable of inflicting on it, as an institution, but also on its students, its faculty and on wider society when those students leave the institution with a degree which they have not entirely earned. To use the words of Gareth Crossman from the UK's QAA, students who engage in contract cheating "are undermining their own education, and...they are also cheating wider society, because you do not want people going out into the workforce who are frankly unqualified". ${ }^{(161)}$ Change is never easy, but change - as well as cooperation and collaboration across the higher education sector - is urgently needed to tackle the global problem of contract cheating.

(160) This claim is made based on commonsense, but it should be the subject of further research: supra n119 and comment in the footnote and main text. Law students, for example, usually have to be free of convictions for dishonesty offences to be admitted to their professional body.

(161) The Essay Cheats, "How students turn to 'essay mills' to help them cheat" BBC.com, 30 March 2019, available at: http://www.bbc.com/capital/story/20190329-the-essay-mills-that-help-students-cheat; my thanks to Dr Lynne Parmenter of the University of Waikato for drawing this article to my attention. 


\section{Bibliography}

\section{Primary Sources}

\section{Legislation}

- Education Act 1989 (NZ) s 292E available at: http://www.legislation. govt.nz/act/public/1989/0080/latest/DLM3988805.html?search=sw_09 6be8ed81826902_292E_25_se\&p=1\&sr=2.

\section{Cases}

- Commissioner of Police v Li [2018] NZHC 1566 [27 June 2018] available at: https://forms.justice.govt.nz/search/Documents/pdf/jdo/44/alfresco/ service/api/node/content/workspace/SpacesStore/17cda54e-0c71-45cca2d1-e07f0de53dfd/17cda54e-0c71-45cc-a2d1-e07f0de53dfd.pdf.

\section{Secondary Sources}

\section{Books}

- Brubacher, J S and Rudy, W Higher Education in Transition: A History of American Colleges and Universities: 1636-1956 (New York, Harper and Brothers: 1958).

- Burke R J, Tomlinson E C and Cooper C L (eds.) Crime and Corruption in Organizations - Why it Occurs and What to do About It (Surrey, Gower Publishing Ltd: 2009).

- McCabe, D, Trevino K and Butterfield, K D Cheating in College: Why Students Do It and What Educators Can Do About It (Baltimore MD: John Hopkins University Press: 2012).

- Pecorari, D Teaching to Avoid Plagiarism: How to Promote Good Source Use (Maidenhead, Open University Press: 2013).

\section{Book Chapters}

- Bretag, $\mathrm{T}$ "Defining Academic Integrity: International Perspectives Introduction" in Bretag (ed) Handbook of Academic Integrity (Singapore, Springer Press: 2016).

- Brimble, M "Why Students Cheat: An Exploration of the Motivators of Student Academic Dishonesty in Higher Education" in Bretag, R (ed.) Handbook of Academic Integrity (Singapore, Springer Press: 2016) chapter 26.

- Fishman, $T$ "Academic Integrity as an Educational Concept, Concern, and Movement in US Institutions of Higher Learning" in Bretag Handbook 
of Academic Integrity (Singapore, Springer Press: 2016).

- Newton, P and Lang, C "Custom Essay-Writers, Freelancers and other Third Parties" chapter 19 in Bretag Handbook of Academic Integrity (Singapore, Springer Press: 2016).

- Stone, T H, Jawahar I M, and Kisamore, J L "Predicting workplace misconduct using personality and academic behaviors" in Burke R J, Tomlinson E C and Cooper C L (eds.) Crime and Corruption in Organizations - why it occurs and what to do about it (Surrey, Gower Publishing Ltd: 2009).

- Thomas, J and Scott, J "UK Perspectives of Academic Integrity" in Bretag et al Handbook of Academic Integrity (Singapore, Springer Press: 2016).

\section{Journal Articles}

- Bretag, T, Harper R, Burton, M, Ellis, C, Newton, P, Rozenburg, P, Saddiqui, S, and van Haeringen, $\mathrm{K}$ "Contract cheating: a survey of Australian university students" (2018) Studies in Higher Education 1-20 DOI: $10.1080 / 03075079.2018 .1462788$

- Brimble, $\mathrm{M}$ and Stevenson-Clarke, $\mathrm{P}$ "Perceptions of the prevalence and seriousness of academic dishonesty in Australian universities" (2005) 32 Australian Educational Researcher 19-44.

- Christensen-Hughes, J M and McCabe, D L "Academic misconduct within higher education in Canada" (2006) 36 The Canadian Journal of Higher Education 1-21, available at: http://journals.sfu.ca/cjhe/index. php/cjhe/article/view/183537/183482.

- Crown, D F and Spiller, M S "Learning from the Literature on Collegiate Cheating: A Review of Empirical Research (1998) 17(6) Journal of Business Ethics 683-700.

- Devlin, M and Gray, K "In their own words: a qualitative study of the reasons Australian university students plagiarize" (2007) Higher Education Research and Development 26(2) 181-198.

- Dix, E L, Emery L F, and Le, B "Committed to the honour code: an investment model analysis of academic integrity" (2014) Social Psychology of Education 17(1) 179-196.

- Drake, C A "Why Students Cheat: A Statistical Search for the Incentives Which Induce College Students to Dishonesty on Examinations" (1941) The Journal of Higher Education 12(8) 418-420 at 418. 
- Draper, M J and Newton, P N "A legal approach to tackling contract cheating?" (2017) 13 International Journal for Educational Integrity 11 available at: https://link.springer.com/article/10.1007/s40979-017-0022-5.

- Elzubier M A and Rizk D E "Exploring perceptions and attitudes of senior medical students and interns on academic integrity" (2003) 37 Medical Education 389-396.

- Gallant, T B and Drinnan, P "Organizational Theory and Student Cheating: Explanation, Responses and Strategy" (2006) 77(5) The Journal of Higher Education 839-860 at 855, available at: https://www. tandfonline.com/doi/abs/10.1080/00221546.2006.11778946.

- Graves, S M and Austin, S F "Student Cheating Habits: A Predictor of Workplace Deviance" (2008) 3(1) Journal of Diversity Management 1521 available at: https://www.researchgate.net/publication/266243962_ Student_Cheating_Habits_A_Predictor_Of_Workplace_Deviance.

- Gullifer, J and Tyson, G A "Exploring university students' perceptions of plagiarism: a focus group study" (2010) Studies in Higher Education 35(4) 463-481 at 464 DOI: 10.1080/03075070903096508.

- Harper, R, Bretag, T, Ellis, C, Newton, P, Rozenburg, P, Saddiqui, S, \& van Haeringen, K "Contract cheating: a survey of Australian university staff" (2018) Studies in Higher Education 1 DOI: $10.1080 / 03075079.2018 .1462789$.

- Jian, H, Russell, M and Wang, W “Academic Integrity From China to the United States: The Acculturation Process for Chinese Graduate Students in the United States" (2019) 29(1) Ethics \& Behaviour 51-70.

- Jones Roberts, C and Hai-Jew, S "An Online Course for Students Addressing Academic Dishonesty" (2009) 5(2) Journal of Online Teaching and Learning 182.

- Lines, L "Ghostwriters guaranteeing grades? The quality of online ghostwriting services available to tertiary students in Australia" (2016) 21(8) Teaching in Higher Education 889-914 available at: https://doi.or $\mathrm{g} / 10.1080 / 13562517.2016 .1198759$.

- MacGregor, K and Stuebs, M "To Cheat or Not to Cheat: Rationalizing Academic Impropriety" (2012) Accounting Education 21(3) 265-287.

- McCabe D L and Trevino, L K "Individual and contextual influences on academic dishonesty: a multi-campus investigation" (1997) 38 Research in Higher Education 379-396. 
- McCabe, D L and Trevino, L K "Academic Dishonesty: Honour codes and other contextual influences" (1993) 64 Journal of Higher Education 522-538.

- McCabe, D L and Trevino, L K "Individual and Contextual Influences on academic dishonesty: A multicampus investigation" (1997) 38 Research in Higher Education 379-396.

- Newton P "Academic integrity: A quantitative study of confidence and understanding in students at the start of their higher education" (2015) Assessment and Evaluation in Higher Education 41(3) 482-497.

- Newton, P and Awdry, R "Staff views on commercial contract cheating in higher education: a survey study in Australia and the UK" (2019) Higher Education 1-18.

- Nonnis S and Swift C "An examination of the relationship between of academic dishonesty and workplace dishonesty: A multicampus investigation" (2001) 76(6) The Journal of Education for Business 69-77.

- Scrimpshire, A J, Stone, T H, Kisamore, J L and Jawahar, I M "Do Birds of a Feather Cheat Together: How Personality and Relationships Affect Student Cheating" (2017) 15(1) Journal of Academic Ethics 2.

- Yakovchuk, N, Badge, J and Scott, J "Staff and student perspectives on the potential of honor codes in the UK" (2011) 7(2) International Journal for Educational Integrity 37-52.

\section{Blogs, News Media, Online-Only Articles}

- Anonymous, "Academia's grey markets offer rich pickings for the untenured" Times Higher Education News 7 March 2019 available at: https://www.timeshighereducation.com/opinion/academias-grey-marketsoffer-rich-pickings-untenured.

- Barret, D and Zapotosky, M "FBI accuses wealthy parents, including celebrities, in college-entrance bribery scheme" Washington Post 12 March 2019 available at: https://www.washingtonpost.com/world/ national-security/fbi-accuses-wealthy-parents-including-celebrities-incollege-entrance-bribery-scheme/2019/03/12/d91c9942-44d1-11e98aab-95b8d80a1e4f_story.html?utm_term=.022e8c731024.

- Basken, P "FBI accuses dozens in elite university admissions bribery case" Times Higher Education 12 March 2019, available at: https://www. timeshighereducation.com/news/fbi-accuses-dozens-elite-universityadmissions-bribery-case. 
- Collins, $\mathrm{T}$ "The 30th anniversary of the World Wide Web: Inventor Tim Berners-Lee calls for people to come together and to stop abuse of the internet" Daily Mail 12 March 2019 available at: https://www.dailymail. co.uk/sciencetech/article-6796403/Tim-Berners-Lee-calls-peoplecome-stop-abuse-internet.html.

- Hackett, G K and Robbins, R D "Cheating Scandal Erupts After ShortAnswer Questions Added to Congress Exam" The Crimson 4 September 2012 available at: https://www.thecrimson.com/article/2012/9/4/ government-exam-harder-questions/.

- Khan, Z "Going Beyond a Day to Become a Voice" ICAI Blog 4 March 2019 available at: https://academicintegrity.org/blog/going-beyond-aday-to-become-a-voice/.

- Matthews, D "Germany's plagiarism hunter spies victory in war on misconduct" Times Higher Education 13 March 2019.

- McKie, A “ $£ 1.3$ billion Turnitin sale spotlights intellectual property fears" Times Higher Education 11 March 2019 available at: https://www. timeshighereducation.com/news/ps13-billion-turnitin-sale-spotlightsintellectual-property-fears.

- McKie, A "Many University staff back prosecuting students over essay mills" Times Higher Education 7 March 2019 available at: https://www. timeshighereducation.com/news/university-staff-back-prosecutingstudents-who-use-essay-mills.

- McNeilage, A and Visentin, L "Students enlist MyMaster website to write essays, assignments" Sydney Morning Herald 12 November 2014 available at: https://www.smh.com.au/education/students-enlistmymaster-website-to-write-essays-assignments-20141110-11k0xg.html.

- MerrionStreet.ie Irish Government News Service "Minister Mitchell O'Connor announces the publication of Qualifications and Quality Assurance (Education and Training) Amendment Bill" 20 July 2018, available at: https://merrionstreet.ie/en/News-Room/Releases/ Minister_Mitchell_O'Connor_announces_the_publication_of_the Qualifications_and_Quality_Assurance_Education_and_Training_ Amendment_Bill.html

- Mohamedbhai, G "Higher Education: a hotbed of corruption?" Center for International Higher Education, 26 July 2015 available at:https:// www.insidehighered.com/blogs/world-view/higher-education-hotbedcorruption. 
- Morgan, J "Website offers 'complete PhD service' for £36" Times Higher Education 24 January 2019, available at: https://www. timeshighereducation.com/news/website-offers-complete-phd-service36-thousand-pounds.

- Moya-Smith, S "Survey: 42\% of Harvard incoming freshmen class cheated on homework" NBC News 7 September 2013 available at: https://www.nbcnews.com/news/us-news/survey-42-percent-harvardsincoming-freshman-class-cheated-homework-flna8C11095144.

- Rao,SandYahr,E“BeforeLoriLaughlin'sallegedcheatingscandaldaughter Olivier Jade made her life at USC a Youtube brand" Washington Post 12 March 2019 available at: https://www.washingtonpost.com/lifestyle/ style/before-lori-loughlins-alleged-cheating-scandal-daughter-oliviajade-made-her-life-at-usc-a-youtube-brand/2019/03/12/d50b5dda-450211e9-8aab-95b8d80a1e4f_story.html?utm_term=.782357ac304d.

- Roberts, M “The college bribery scandal is all about a myth" Washington Post 13 March 2019 available at: https://www.washingtonpost.com/ opinions $/ 2019 / 03 / 13 /$ meritocracy-is-myth-this-is-who-keeps-italive/?utm_term $=$.fa7cb2b891be.

- Sundiata Post "UOWD Staff and Students Unite in the Fight Against Academic Misconduct" 28 January 2019, available at: https:// sundiatapost.com/2019/01/28/uowd-staff-and-students-unite-in-thefight-against-academic-misconduct/.

- Tennant, P and Duggan, F "Academic Misconduct Benchmarking Research Project Part II: The Recorded Incidence of Student Plagiarism and the Penalties Applied" May 2008, available to download from here: https://www.plagiarism.org/paper/academic-misconduct-benchmarkingresearch-project-part-2.

- The Essay Cheats, "How students turn to 'essay mills' to help them cheat" BBC.com, 30 March 2019, available at: http://www.bbc.com/ capital/story/20190329-the-essay-mills-that-help-students-cheat.

- The FBI affidavit of FBI Special Agent Laura Smith, indicting the accused, is available here: https://games-cdn.washingtonpost.com/notes/ $\mathrm{prod} / \mathrm{default} /$ documents/d216435e-e073-41f6-b6fa-33ed835d053d/ note/1310d5d4-ef15-4ea9-ad35-5edaac10cbb5.pdf.

- Universities New Zealand "We need to talk about cheating" 21 August 2018 available at: https://www.universitiesnz.ac.nz/latest-news-andpublications/we-need-talk-about-cheating. 
- US Federal News Service "University of Texas System Teaching College Students Intervention Strategies to Curb Sexual Assaults, Cheating, Suicide and Racism" 10 September 2015.

- Van Beynan, M, Lee, F and Dudding, A "Chinese cheats rort New Zealand universities with fakes" Stuff News 12 Mary 2013, available at: http://www.stuff.co.nz/national/education/8662224/Chinese-cheats-rortNZ-universities-with-fakes.

- Visentin, L "MyMaster essay cheating scandal: more than 70 university students face suspension" Sydney Morning Herald, 18 March 2015, available at: https://www.smh.com.au/national/nsw/mymaster-essaycheating-scandal-more-than-70-university-students-face-suspension20150312-1425oe.html.

\section{Reports}

- QAA, "Contracting to Cheat in Higher Education: How to Address Contract Cheating, the Use of Third Party Services and Essay Mills" (QAA, 2017) available at: https://www.qaa.ac.uk/docs/qaa/quality-code/ contracting-to-cheat-in-higher-education.pdf?sfvrsn=f66af681_8.

- QAA, "Plagiarism in Higher Education - Custom essay writing services: an exploration and next steps for the UK higher education sector" (QAA, 2016) available at: https://www.qaa.ac.uk/docs/qaa/quality-code/ plagiarism-in-higher-education-2016.pdf?sfvrsn=308cfe81_4.

- University of Sydney's report, An Approach to Minimising Academic Misconduct and Plagiarism at the University of Sydney, Part 1: Prevention and Detection available at: https://www.smh.com.au/cqstatic/givnzv/ Taskforce.pdf.

\section{Conferences/Meetings}

- Clarke, R and Lancaster, $\mathrm{T}$ "Eliminating the Successor to Plagiarism? Identifying the Usage of Contract Cheating Sites" (2006) Proceedings of the 2nd International Plagiarism Conference available at: https://www. plagiarism.org/assets/Clarke2_fullpaper2006.pdf.

- Proceedings of the 2nd Plenary Meeting of the Council of Europe Platform on Ethics, Transparency and Integrity in Education (ETINED), 15-16 February 2018, programme and links to presentations available at: https:// rm.coe.int/etined-2018-programme-and-powerpoints/16808aa93f. 


\section{Websites}

- Contract Cheating and Assessment Design available at: https:// cheatingandassessment.edu.au/.

- Contract Cheating and Assessment Design Project, "Institution" available at: https://cheatingandassessment.edu.au/institution/.

- EduBirdie "Terms and Conditions", updated 25 July 2018, available at: https://edubirdie.com/terms.

- Gallant, T "Twenty Years of Academic Integrity: Top Articles and Book Chapters 2002-2012" (ICAI, 2012) available at: https://academicintegrity. org/wp-content/uploads/2017/12/462c19_88fa30a3dcff420bb6b3ea846 97d8b1b.pdf.

- ICAI "Statistics" available at: https://academicintegrity.org/statistics/.

- ICAI, "Our member Institutions" available at: https://academicintegrity. org/about/our-member-institutions-2/.

- ICAI, The Fundamental Values of Academic Integrity (ICAI, 2012) available at: https://academicintegrity.org/wp-content/uploads/2017/12/ Fundamental-Values-2014.pdf.

- International Centre for Academic Integrity (ICAI), available at: www. academicintegrity.org.

- Kuwait International Law School's "Values", available at: https:// kilaw.edu.kw/vision-mission-goals-objectives-and-strategicapproaches/\#1543945373674-c5a9f985-267b.

- The Collegiate Way "Yale Report" available at: http://collegiateway.org/ reading/yale-report-1828/.

- University of Otago, "Academic Integrity Policy", took effect on 1 August 2015, available at: https://www.otago.ac.nz/administration/ policies/otago116838.html.

\section{Video/Documentary}

- SBS, "Pens for Hire (The Feed)" 10 November 2015 available at: https:// www.sbs.com.au/ondemand/video/563219523562/pens-for-hire-the-feed. 
Table of Contents

\begin{tabular}{|l|c|}
\hline Subject & Page \\
\hline Abstract & 219 \\
\hline 1.Introduction & 221 \\
\hline 2.The big picture: academic integrity and student cheating & 223 \\
\hline 2.1 Academic integrity & 223 \\
\hline 2.2 Honesty & 228 \\
\hline 2.3 Student cheating & 228 \\
\hline What activities does student cheating entail? & 229 \\
\hline How often does cheating happen? & 229 \\
\hline Why do students cheat? & 232 \\
\hline 3.Contract cheating - a particularly insidious type of cheating & 233 \\
\hline $\begin{array}{l}\text { 4.What can universities do to prevent and combat contract } \\
\text { cheating? }\end{array}$ & 237 \\
\hline $\begin{array}{l}\text { 5.The legal response: what governments can do to prevent } \\
\text { contract cheating }\end{array}$ & 246 \\
\hline 5.1 New Zealand & 246 \\
\hline The pros and cons of the New Zealand legislative approach & 250 \\
\hline Should students be criminally prosecuted for contract cheating? & 252 \\
\hline $\begin{array}{l}\text { Aside from New Zealand, who else is criminalizing contract } \\
\text { cheating? }\end{array}$ & 255 \\
\hline $\begin{array}{l}\text { 6.What can quality assurance agencies do to prevent and } \\
\text { combat contract cheating? }\end{array}$ & 256 \\
\hline \begin{tabular}{l} 
7.Recommendations \\
\hline 8.Conclusion
\end{tabular} & 258 \\
\hline Bibliography & 265 \\
\hline & 266 \\
\hline
\end{tabular}

